\title{
Pressure- and stress-induced fabric transition in olivine from peridotites in the Western Gneiss Region (Norway): implications for mantle seismic anisotropy
}

\author{
Q. WANG, ${ }^{1}$ Q.-K. XIA, ${ }^{2}$ S. Y. O'REILLY, ${ }^{3}$ W. L. GRIFFIN, ${ }^{3}$ E. E. BEYER ${ }^{3,4}$ AND H. K. BRUECKNER ${ }^{3,5}$ \\ ${ }^{1}$ State Key Laboratory for Mineral Deposits Research, Department of Earth Sciences, Nanjing University, Nanjing 210093, \\ China (qwang@nju.edu.cn) \\ ${ }^{2}$ School of Earth and Space Sciences, University of Science and Technology of China, Hefei 230026, China \\ ${ }^{3}$ Australian Research Council Centre of Excellence for Core to Crust Fluid Systems and GEMOC, Department of Earth and \\ Planetary Sciences, Macquarie University, NSW 2109, Australia \\ ${ }^{4}$ Northern Territory Geological Survey, Department of Resources, Alice Springs, NT 0871, Australia \\ ${ }^{5}$ Lamont-Doherty Earth Observatory of Columbia University, Palisades, NY 10964, USA
}

ABSTRACT The effects of pressure, water and differential stress on the crystallographic preferred orientation (CPO) of olivine were investigated by an integrated study on 13 peridotite samples from four areas in the Western Gneiss Region (WGR) of the Norwegian Caledonides. The highly depleted dunites are mantle residues after Archean melt extraction, while the garnet peridotites were formed by refertilization of the dunites via melt percolation in the Proterozoic. These orogenic peridotites were tectonically emplaced into Proterozoic gneisses and metasedimentary rocks of the WGR and were recrystallized under highpressure (HP) to ultrahigh-pressure (UHP) conditions when the Baltic Shield was subducted beneath Laurentia during the 420-400 Ma Scandian orogeny. The CPOs of olivine, enstatite and diopside were measured using the electron backscatter diffraction technique. The weakly deformed garnet wehrlites and dunites from the HP central WGR (the Gurskøy, Almklovdalen and Tafjord areas) show the A-type olivine fabric defined by the [100] axis subparallel to the stretching lineation and the (010) plane subparallel to the foliation, which may be a relict fabric formed at high temperature and low strain rate in the mantle wedge prior to subduction. The [001](010) fabric (B-type) is observed in strongly sheared HP garnet peridotites and dunites from the Almklovdalen and Tafjord areas, suggesting the dominant activation of [001](010) slip system at high stress and high strain rate. Recrystallized fine olivine grains may develop a fabric different from porphyroclasts and record a gradual fabric transition. The olivine CPO in garnet lherzolites from Otrøy in the northernmost WGR is characterized by the concentration of [001] axes parallel to the stretching lineation and [100] axes normal to the foliation, indicating a prevailing [001](100) slip (C-type fabric) at $P-T$ conditions of $>6 \mathrm{GPa}$ and $850-950{ }^{\circ} \mathrm{C}$. Despite very different deformation microstructures, Fourier transform infrared analysis reveals very low water contents ( $<13 \mathrm{ppm} \mathrm{H}_{2} \mathrm{O}$ by the Paterson calibration) in olivine for both coarse porphyroclasts and recrystallized small grains, which is consistent with the high-degree partial melting of the peridotites during the Archean. Therefore, a combination of UHP and low temperature plays a more important role than water in promoting the C-type olivine fabric in a dry, cold and deeply subducted continental slab. With increasing subduction depths, the C-type olivine fabric will predominate over the A-type fabric and make the maximum $\mathrm{P}$-wave velocity and shear wave splitting of peridotites normal to the foliation. However, the stress-induced fabric transition in olivine from the A-type to the B-type may be localized in shear zones and not distinguishable in seismic anisotropy observations.

Key words: crystallographic preferred orientation; olivine; seismic anisotropy; subduction zone; water.

\section{INTRODUCTION}

The relationship between plastic deformation and seismic anisotropy of peridotites is critical for the interpretation of seismic anisotropy in the upper mantle. Since the 1960s, deformation experiments on mantle rocks and olivine aggregates have revealed a predominant crystallographic preferred orientation
(CPO) of olivine, which is characterized by the olivine [100] axis and (010) plane parallel to the shear direction and the shear plane, respectively (A-type fabric; e.g. Raleigh, 1968; Carter \& Avé Lallemant, 1970; Zhang et al., 2000). The fabric analysis of naturally deformed peridotites (Ben Ismaïl \& Mainprice, 1998) and numerical modelling of olivine alignment (Blackman et al., 2000; Tommasi et al., 2000) have confirmed that 
olivine deforms essentially by dislocation creep with the $[100](010)$ slip system under upper mantle conditions. Therefore, the olivine A-type fabric has been widely used to link the seismic anisotropy of the upper mantle with plate dynamics (e.g. Savage, 1999; Park \& Levin, 2002).

However, the critical shear stress for activation of certain glide systems during deformation may depend on pressure, temperature, differential stress, strain rate and fluid activity. Recent experiments found that water (in the form of hydrogen dissolved in lattice defects; Jung \& Karato, 2001; Katayama et al., 2004; Jung et al., 2006) and UHP (Couvy et al., 2004; Durinck et al., 2005; Mainprice et al., 2005; Raterron et al., 2007; Jung et al., 2009; Ohuchi et al., 2011) can change the easiest slip direction in olivine from [100] to [001] and lead to different CPOs. Although it is still debated whether high water content or UHP/low temperature is the key parameter for the fabric transition in olivine (Ji et al., 2007; Karato et al., 2008), it is noteworthy that some orogenic garnet peridotite bodies from UHP metamorphic terranes display either [001](010) (B-type) or [001](100) (C-type) olivine fabric, for example, Cima di Gagnone in the central Alps (Frese et al., 2003; Skemer et al., 2006), the Western Gneiss Region (WGR) of the Norwegian Caledonides (Katayama et al., 2005), and the Sulu terrane in China (Xu et al., 2006). Despite their different origins and water contents, all these orogenic peridotites were subducted to depths of $80-200 \mathrm{~km}$ and exhumed rapidly along with the surrounding gneisses. If they developed the Atype fabric of olivine prior to subduction, the fabric transition in olivine under different thermal-mechanical conditions will produce characteristic change in the seismic anisotropy of the upper mantle (e.g. Katayama \& Karato, 2006; Long \& Becker, 2010).

The peridotites in the WGR represent Archean mantle fragments embedded in the Proterozoic Baltic continental crust (Beyer et al., 2004, 2006; Lapen et al., 2009; Brueckner et al., 2010). They experienced deformation and eclogite facies metamorphism during the Late Silurian-Early Devonian collision between Baltica and Laurentia (Carswell \& Cuthbert, 2003 and references therein; Scambelluri et al., 2008). Based on an integrated study of geochemistry, petrofabrics, seismic anisotropy and water contents for dunites and garnet peridotites from the WGR, we address three main questions: (i) Can Archean and Proterozoic mantle fabrics be distinguished from later orogenic fabrics in the WGR peridotites? (ii) What is the role of pressure and water in the fabric development of olivine in continental subduction zones, where fluid activity is very limited compared with oceanic subduction zones? (iii) What are the tectonic and geophysical implications of different olivine fabric types? Answers to these questions will not only improve understanding of orogenic peridotites but also give new insights into deformation and the seismic anisotropy in subduction zones.

\section{GEOLOGICAL SETTING}

The WGR is $300 \mathrm{~km}$ long and $150 \mathrm{~km}$ wide, stretching along the western coast of Norway from Bergen in the south to Trondheim in the north (Fig. 1). It represents the structurally lowest unit in the southern Scandinavian Caledonides and is predominantly composed of amphibolite to granulite facies orthogneisses and paragneisses, with widespread pods and lenses of eclogites and peridotites (Brueckner \& Medaris, 2000; Carswell \& Cuthbert, 2003). The protolith ages of tonalitic to granodioritic orthogneisses are mostly between $c$. 1750-1500 Ma (Gothian orogeny) and 1250-900 Ma (Sveconorwegian orogeny) (Austreim et al., 2003; Skår \& Pedersen, 2003; Beyer et al., 2012). The mantle-derived peridotite bodies include garnet-free Archean dunites with extremely depleted compositions, and $\mathrm{Mg}-\mathrm{Cr}$ type garnet peridotites produced by refertilization of the dunites during Proterozoic time (Brueckner \& Medaris, 2000; Beyer et al., 2004, 2006; Spengler et al., 2006; Lapen et al., 2009; Brueckner et al., 2010).

During the Late Silurian-Early Devonian collision between Baltica and Laurentia (Scandian orogeny), the Proterozoic Baltic crust was subducted northwestward beneath the Laurentian plate and collected peridotites from the overlying mantle wedge (Torsvik, 1998; Terry \& Robinson, 2004; Brueckner et al., 2010; Beyer et al., 2012). These rocks were subjected to HP-UHP metamorphism at $1.8-3.6 \mathrm{GPa}$ and $600-800{ }^{\circ} \mathrm{C}$ between 420 and $400 \mathrm{Ma}$ (Dobrzhinetskaya et al., 1995; Van Roermund et al., 2002; Vrijmoed et al., 2006). However, majoritic (i.e. high silica) garnet in garnet peridotites and websterites from the Nordøyane UHP domain records a pressure of 6-6.5 GPa during the Scandian event, suggesting a much deeper subduction depth for the Nordøyane UHP domain than for the southern WGR (Scambelluri et al., 2008). Subsequently, the WGR was exhumed nearly isothermally to depths of $15-20 \mathrm{~km}$ and subjected to an overprint of amphibolite facies retrogression at $0.5-1.5 \mathrm{GPa}$ and $650-850{ }^{\circ} \mathrm{C}$ between 400 and $380 \mathrm{Ma}$ (Terry \& Robinson, 2003; Hacker et al., 2010). The antiformal structures of the Nordfjord-Stadlandet and Sorøyane UHP domains were formed at amphibolite facies conditions during exhumation of the WGR to the middle crust (Root et al., 2005; Hacker, 2007).

\section{SAMPLE LOCALITIES AND PETROGRAPHY}

Hundreds of peridotite bodies are widely distributed across the WGR as tectonic lenses with dimension of metres to kilometres. Small volumes of garnet peridotite occur locally as discrete zones within large bodies of garnet-free, chromite-bearing Archean dunites and harzburgites. The garnet peridotites are usually associated with garnet pyroxenites and probably were fertilized by interactions of the dunites with the pyroxenite melts in Proterozoic time (Brueckner \& 


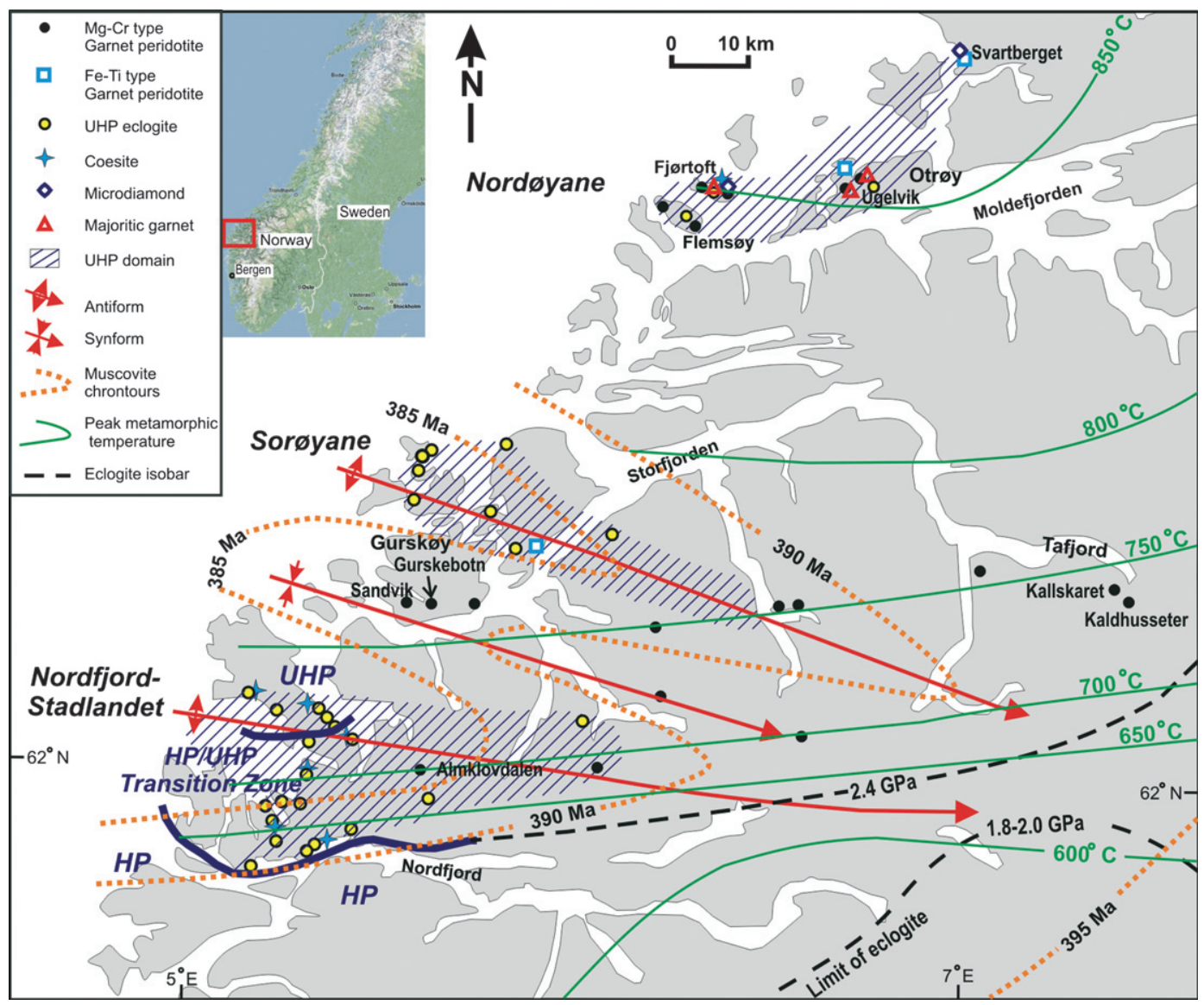

Fig. 1. Distribution of orogenic peridotite bodies and ultrahigh-pressure (UHP) eclogites in the Western Gneiss Region, Norway (modified after Beyer et al., 2004 and Root et al., 2005). Boundaries of the three UHP domains, muscovite ${ }^{40} \mathrm{Ar} /{ }^{39} \mathrm{Ar}$ age contours and the fold axes are after Root et al. (2005) and Hacker (2007). The thick blue lines delineate the high pressure (HP)-UHP transition zone with mixed UHP (coesite-stable) and HP (quartz-stable) eclogites (Carswell \& Cuthbert, 2003), which can be extended eastward using the eclogite isobar of $2.4 \mathrm{GPa}$ by Hacker et al. (2010). The thin green lines show northwestward-increasing peak metamorphic temperature (Kylander-Clark et al., 2008).

Medaris, 2000; Beyer et al., 2006; Lapen et al., 2009; Brueckner et al., 2010). In order to cover the different metamorphic and deformation conditions in subduction zones, 13 peridotite samples were selected from four areas: Almklovdalen in the Nordfjord-Stadlandet HP/UHP transition zone, Otrøy in the Nordøyane UHP domain, the Gurskøy HP area between the Nordfjord-Stadlandet and Sorøyane UHP domains, and the Tafjord HP area in the eastern WGR (Fig. 1). Thin sections were cut parallel to the structural $X Z$ plane $(X-$ parallel to the lineation, $Y$ - parallel to foliation and normal to lineation, $Z$ - normal to foliation). The modal compositions are based on optical observations under microscope and electron backscatter diffraction (EBSD) analysis on thin sections (Table 1).

\section{Peridotites from Almklovdalen}

The Almklovdalen peridotite body is located $\sim 10 \mathrm{~km}$ north of Nordfjord in the southern WGR (Fig. 1). It occurs as a bowl-shaped inclined synform extending several kilometres to the southeast below the surrounding gneisses (Cordellier et al., 1981). The dunites are locally chloritized and show well-developed foliation and lineation. The foliation and garnet pyroxenite layers were intensely deformed by several fold generations, with geometries, hinges and axial surfaces parallel to folds in the enclosing gneisses (Medaris, 1980; Cordellier et al., 1981). Three garnet lherzolite samples N97-5, N97-14 and N97-18 are characterized by porphyroclastic texture, with large porphyroclasts (up to $1 \mathrm{~cm}$ ) of garnet, pyroxene and olivine in a finegrained $(<0.5 \mathrm{~mm})$ matrix of recrystallized olivine and pyroxene. Porphyroclasts of pyroxene and olivine show strong undulose extinction, and in some instances, kink bands (Fig. 2a). Kelyphite rims on garnet are variably developed and may be surrounded by partial collars of coarse-grained amphibole and spinel (Fig. 2b), which were interpreted as recrystallization of kelyphite by Carswell (1968). In mylonitic sample N97-5 from the Raudkleivane peridotite body, 
Table 1. Sample locality, modal composition and microstructure of the Western Gneiss Region peridotites.

\begin{tabular}{|c|c|c|c|c|}
\hline Sample & Lithology & Locality & Modal composition (vol\%) & Microstructure \\
\hline N97-5 & Garnet lherzolite & Raudkleivane, Almklovdalen & $5 \mathrm{Grt}, 84 \mathrm{Ol}, 2 \mathrm{Opx}, 6 \mathrm{Cpx}, 2 \mathrm{Amp}, 1 \mathrm{Chr}$ & Porphyroclastic, strongly sheared mylonite \\
\hline N97-14 & Garnet lherzolite & Helgehornsvatn, Almklovdalen & $4 \mathrm{Grt}, 65 \mathrm{Ol}, 4 \mathrm{Opx}, 9 \mathrm{Cpx}, 2 \mathrm{Amp}, 15 \mathrm{Srp}, 1 \mathrm{Chr}$ & Porphyroclastic, moderately serpentinized \\
\hline N97-18 & Garnet lherzolite & Helgehornsvatn, Almklovdalen & 5 Grt, $57 \mathrm{Ol}, 10 \mathrm{Opx}, 20 \mathrm{Cpx}, 3 \mathrm{Amp}, 4 \mathrm{Chl}, 1 \mathrm{Chr}$ & Porphyroclastic \\
\hline N97-8 & Dunite & Raudkleivane, Almklovdalen & $90 \mathrm{Ol}, 5 \mathrm{Opx}, 1 \mathrm{Amp}, 3 \mathrm{Chl}, 1 \mathrm{Phl}, 1 \mathrm{Chr}$ & Shape-preferred orientation and sigmoids of olivine \\
\hline N97-9 & Dunite & Raudkleivane, Almklovdalen & $90 \mathrm{Ol}, 1 \mathrm{Opx}, 2 \mathrm{Cpx}, 1 \mathrm{Amp}, 5 \mathrm{Chl}, 1 \mathrm{Chr}$ & Shape-preferred orientation and sigmoids of olivine \\
\hline N97-13 & Dunite & Raudkleivane, Almklovdalen & $92 \mathrm{Ol}, 3 \mathrm{Opx}, 1 \mathrm{Amp}, 3 \mathrm{Chl}, 1 \mathrm{Chr}$ & Shape-preferred orientation of olivine \\
\hline N97-40 & Garnet harzburgite & Ugelvik, Otrøy & $10 \mathrm{Grt}, 40 \mathrm{Ol}, 10 \mathrm{Opx}, 7 \mathrm{Cpx}, 30 \mathrm{Srp}, 2 \mathrm{Amp}, 1 \mathrm{Chr}$ & Porphyroclastic, serpentinized \\
\hline N97-41 & Garnet harzburgite & Ugelvik, Otrøy & $8 \mathrm{Grt}, 38 \mathrm{Ol}, 11 \mathrm{Opx}, 5 \mathrm{Cpx}, 35 \mathrm{Srp}, 2 \mathrm{Amp}, 1 \mathrm{Chr}$ & Porphyroclastic, serpentinized \\
\hline GBWG & Garnet wehrlite & Gurskebotn, Gurskøy & $20 \mathrm{Grt}, 40 \mathrm{Ol}, 15 \mathrm{Opx}, 24 \mathrm{Cpx}, 1 \mathrm{Chr}$ & Porphyroclastic, protomylonite \\
\hline N97-30 & Garnet wehrlite & Gurskebotn, Gurskøy & $10 \mathrm{Grt}, 74 \mathrm{Ol}, 5 \mathrm{Opx}, 10 \mathrm{Cpx}, 1 \mathrm{Chr}$ & Porphyroclastic, protomylonite \\
\hline TO & Dunite & Kallskaret, Tafjord & $99 \mathrm{Ol}, 1 \mathrm{Chr}+\mathrm{Tre}+\mathrm{Chr}$ & Granoblastic, weakly sheared \\
\hline $\mathrm{K}-\mathrm{i}-\mathrm{I}$ & Dunite & Kallskaret, Tafjord & 92 Ol, 2 Opx, 4 Chl, 1 Amp, $1 \mathrm{Chr}$ & Porphyroclastic, strongly sheared mylonite \\
\hline I-A & Dunite & Kaldhusseter, Tafjord & $97 \mathrm{Ol}, 1 \mathrm{Opx}, 1 \mathrm{Chl}, 1 \mathrm{Cpx},<1 \mathrm{Chr}+\mathrm{Tlc}$ & Porphyroclastic, strongly sheared mylonite \\
\hline
\end{tabular}

the foliation and stretching lineation are defined by elongated olivine and pyroxene and trails of garnet porphyroclasts. Sample N97-14 from the Helgehornsvatn (Lien) locality has serpentine veins that crosscut porphyroclasts as well as the kelyphite rims, suggesting that serpentinization postdates deformation and recrystallization of the reaction coronas.

In contrast to the garnet peridotites, dunite samples N97-8, N97-9 and N97-13 from Raudkleivane contain $>90 \%$ olivine with minor orthopyroxene, clinopyroxene, chlorite, amphibole and chromite. Olivine is either equigranular or elongated, with the grain size varying from 0.1 to $3 \mathrm{~mm}$. The foliation and lineation are defined by elongated olivine grains and discrete flakes or ribbons of chlorite (Fig. 2c). In addition, recrystallized olivine and orthopyroxene aggregates can form sigmoids (Fig. 2d).

\section{Garnet harzburgites from Otrøy}

The occurrence of majoritic garnet demonstrates that the Ugelvik garnet peridotite body on Otrøy in the Nordøyane UHP domain was exhumed from $>185 \mathrm{~km}$ depth (Scambelluri et al., 2008). Samples N97-40 and N97-41 are moderately serpentinized garnet harzburgites. Despite a network of serpentine veins, large porphyroclasts of garnet, olivine and orthopyroxene can be recognized and a stretching lineation is defined by elongated olivine and pyroxene (Fig. 2e,f). The aspect ratios of elongated olivine porphyroclasts are up to $6: 1$, implying significant strain of these samples under UHP. A similar case has been observed in garnet peridotites from the Sulu UHP terrane (China), with the aspect ratios of elongated olivine grains up to 10:1 (Xu et al., 2006). In addition, fresh, small euhedral orthopyroxene grains $(\sim 0.3 \mathrm{~mm})$ are observed in the matrix (Fig. 2e).

\section{Garnet wehrlites from Gurskøy}

The Gurskebotn peridotite body on the island of Gurskøy is located between the Nordfjord-Stadlandet and the Sorøyane UHP domains and was subjected to HP metamorphism and deformation during the Scan- dian orogeny (Jamtveit, 1984; Lapen et al., 2009). Two fresh garnet wehrlite protomylonites, GBWG and N97-30, show porphyroclastic texture. Large porphyroclasts of garnet have kelyphite rims and may contain rounded clinopyroxene. In some cases, garnet is totally replaced by chlorite. Olivine and pyroxene either occur as porphyroclasts of $1-5 \mathrm{~mm}$ size with intensive undulose extinction and kink bands or occur as thin lensoid shear zones with grain sizes of $0.01-$ $0.1 \mathrm{~mm}$ (Fig. 2g,h). Grain boundaries of both porphyroclasts and recrystallized fine grains are strongly curved and interlobate in response to grain boundary migration. The mechanical twinning in clinopyroxene porphyroclasts can be attributed to deformation under low temperature and high strain rate (e.g. Godard \& Van Roermund, 1995).

\section{Dunites from Tafjord}

As the easternmost exposure of garnet-bearing ultramafic rocks in the WGR, two large ultramafic masses in the Tafjord area occur within recumbent folds near Kaldhusseter and Kallskaret, respectively. The Kaldhusseter peridotite body is $\sim 1300 \mathrm{~m}$ long and $\sim 100 \mathrm{~m}$ wide, while at Kallskaret, numerous peridotite lenses, some as long as $600 \mathrm{~m}$, are distributed over an area of $1.5 \mathrm{~km}^{2}$. The ultramafic rocks display a schistosity defined by flattened olivine grains and alignment of chlorite flakes, and a primary lineation defined by alignment of tremolite, enstatite, elongated olivine and trails of olivine and chromite. The orientation of the schistosity and lineation of peridotites is parallel to those of the surrounding almandine-amphibolite facies schists and amphibolites. Furthermore, fourfold generations in the peridotites are also present in the gneisses with identical orientations. Thus, the peridotites and gneisses were subjected to the Caledonian deformation and metamorphism together (Brueckner, 1969, 1977). A similar suggestion has been made for the Almklovdalen peridotites and the enclosing gneisses (Medaris, 1980).

The dunite sample TO from Kallskaret is very fresh, characterized by $99 \%$ olivine with a few grains of chromite. The granoblastic fabric of relatively coarse- 

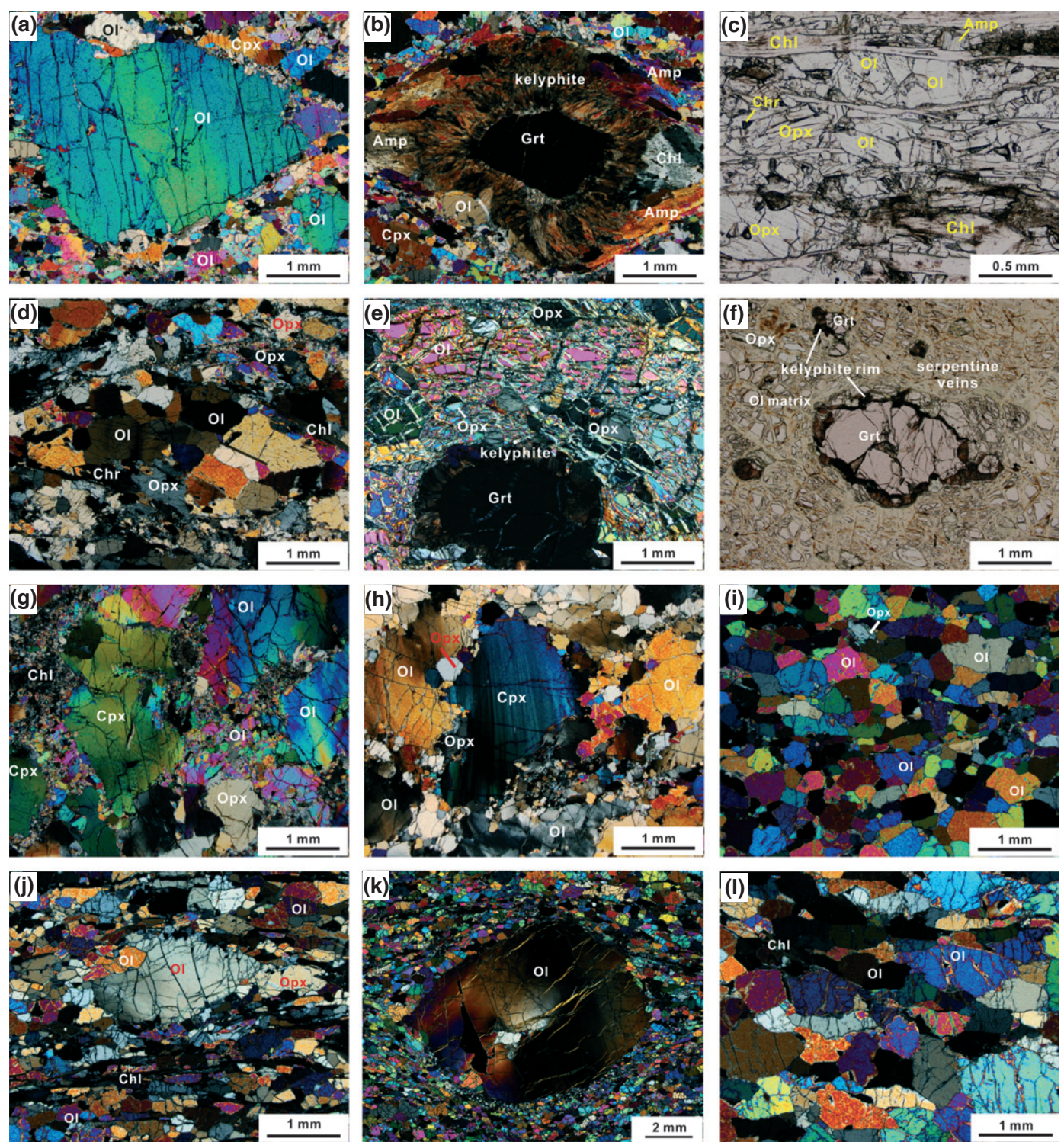

Fig. 2. Photomicrographs showing microstructures and mineral assemblages of the Western Gneiss Region peridotites: (a) Ol porphyroclast in recrystallized $\mathrm{Ol}$ and Pyx, and (b) $\sigma$-type porphyroclast of Grt and its kelyphite rim in Grt lherzolite N97-5 from

Raudkleivane in Almklovdalen; (c) elongated olivine grains and discrete flakes or ribbons of chlorite, and (d) sigmoid of Ol and Opx aggregates in dunite N97-9 from Raudkleivane in Almklovdalen; (e) an elongated O1 grain cut by serpentine veins and fresh recrystallized small Opx grains in garnet harzburgite N97-40 from Ugelvik, Otrøy; (f) a network of serpentine veins in garnet harzburgite N97-41 from Ugelvik, Otrøy; (g) porphyroclasts of Pyx and Ol with undulose extinction and kink bands in Grt wehrlite GBWG from Gurskøy; (h) deformation twin of Cpx porphyroclast and subgrains of Ol in Grt wehrlite N97-30 from Gurskebotn in Gurskøy; (i) granoblastic fabric and weak foliation in dunite TO from Kallskaret in Tafjord; (j, k) $\sigma$-type Ol porphyroclasts in chlorite dunite K-i-I from Kallskaret in Tafjord. (1) Shape-preferred orientation of flattened olivine in dunite I-A from Kaldhusseter in Tafjord. Except (g) and (h), all images are taken from $X Z$ sections with $X$ parallel to the horizontal edge. Abbreviations of mineral names are after Whitney \& Evans (2010).

grained olivine $(0.2-1 \mathrm{~mm})$ appears to record static recrystallization under mantle conditions (Fig. 2i). A weak lineation is defined by slightly elongated olivine grains. Chromite generally appears as small interstitial grains between polygonal olivine crystals, but occasionally as large grains including rounded olivine. Sample K-i-I is a strongly deformed chlorite dunite from the highly sheared upper level of the Kallskaret body. The stretching lineation is defined by elongated olivine and pyroxene, ribbons of platy chlorite and associated chromite (Fig. 2j), and is parallel to the lineation of the surrounding gneisses. A huge $\sigma$-type olivine porphyroclast up to $1 \mathrm{~cm}$ in size occurs within a matrix of elongated olivine and orthopyroxene, and ribbons of chlorite (Fig. 2k).

In contrast, sample I-A is a slightly chloritized, sheared dunite from Kaldhusseter, composed of $95 \%$ olivine, minor orthopyroxene, chlorite, tremolite and 
very few chromite and clinopyroxene grains. The shape-preferred orientation of olivine grains and discrete chlorite flakes define the lineation (Fig. 21), which is parallel to the lineation in the surrounding gneisses. Old olivine grains appear as large porphyroclasts $(\sim 5 \mathrm{~mm}$ in average long axis) with undulose extinction.

\section{MAJOR-ELEMENT COMPOSITION}

Analytical methods are outlined in Appendix S1. Table S1 lists the whole-rock major-element contents of the WGR peridotite samples. The $\mathrm{Mg} \#, \mathrm{CaO}$ and $\mathrm{Al}_{2} \mathrm{O}_{3}$ values of our samples, the primitive mantle (McDonough \& Sun, 1995), and the mean Archean and Proterozoic lithospheric mantle (Griffin et al., 2003) are plotted in Fig. 3. The Mg\# for the WGR garnet peridotites varies from 90.5 to 92.9 , indicating that the garnet-bearing rocks are moderately to weakly refractory relative to the primitive mantle. This feature is consistent with their relatively low contents of $\mathrm{Al}_{2} \mathrm{O}_{3}$ and $\mathrm{CaO}$. Most garnet-bearing samples fall between and around the mean estimates of the Archean and Proterozoic mantle, that is, 'Archon' and 'Proton' of Griffin et al. (2003). Except for garnet lherzolite N97$5, \mathrm{Na}_{2} \mathrm{O}$ contents of the garnet peridotites and dunites are lower than the primitive mantle, consistent with their $\mathrm{Cpx} /$ amphibole-poor modal compositions. In contrast to the garnet peridotites, the five dunite samples from the Almklovdalen and Tafjord areas are strongly depleted with $\mathrm{Mg} \#$ of 92.4-93.8 and low $\mathrm{Al}_{2} \mathrm{O}_{3}$ and $\mathrm{CaO}$ contents, which can be explained by $>90 \mathrm{vol} \%$ of olivine and the lack of $\mathrm{Ca}-\mathrm{Al}$-bearing phases such as garnet.

$\mathrm{Mg} \#$ values of olivine range 90.5-90.8 for garnet lherzolites from Almklovdalen, 91.9-93.2 for garnet wehrlites from Gurskebotn, and 91.9-92.3 for garnet harzburgites from Ugelvik (Table S2). Except for garnet wehrlite GBWG, the garnet peridotites and dunites follow a positive correlation between the olivine $\mathrm{Mg \#}$ and the whole-rock Mg\# (Fig. 4). Sample GBWG is characterized by an extremely high olivine $\mathrm{Mg} \#$ of 93.2, relatively high contents of $\mathrm{Al}_{2} \mathrm{O}_{3}$ and $\mathrm{CaO}$, and abundant garnet and clinopyroxene, implying that it experienced significant metasomatism after primary high-degree partial melting.

Orthopyroxene has compositions of $E_{91.2}$ to $E_{91.4}$ in the garnet peridotites from Almklovdalen, and $\mathrm{En}_{92.4}$ to $\mathrm{En}_{92.7}$ in garnet harzburgites $\mathrm{N97-40}$ and N97-41 from Ugelvik (Table S3). Garnet wehrlite GBWG has orthopyroxene of $E_{193.2}$, which is similar to values of $E_{93.1}$ and $E_{92.7}$ in dunites N97-8 and N97-13, respectively, underlining the highly depleted nature of GBWG. Clinopyroxene in garnet peridotites N97-14, N97-18, GBWG and N97-30 display diopside compositions of $\mathrm{En}_{47-50} \mathrm{Fs}_{1.9-3.4} \mathrm{Wo}_{48-51}$ (Table S4). Diopside in sample GBWG has higher contents of $\mathrm{Al}_{2} \mathrm{O}_{3}, \mathrm{TiO}_{2}$ and $\mathrm{Na}_{2} \mathrm{O}$, but is less rich in $\mathrm{Cr}_{2} \mathrm{O}_{3}$ and $\mathrm{CaO}$ than the other three samples.
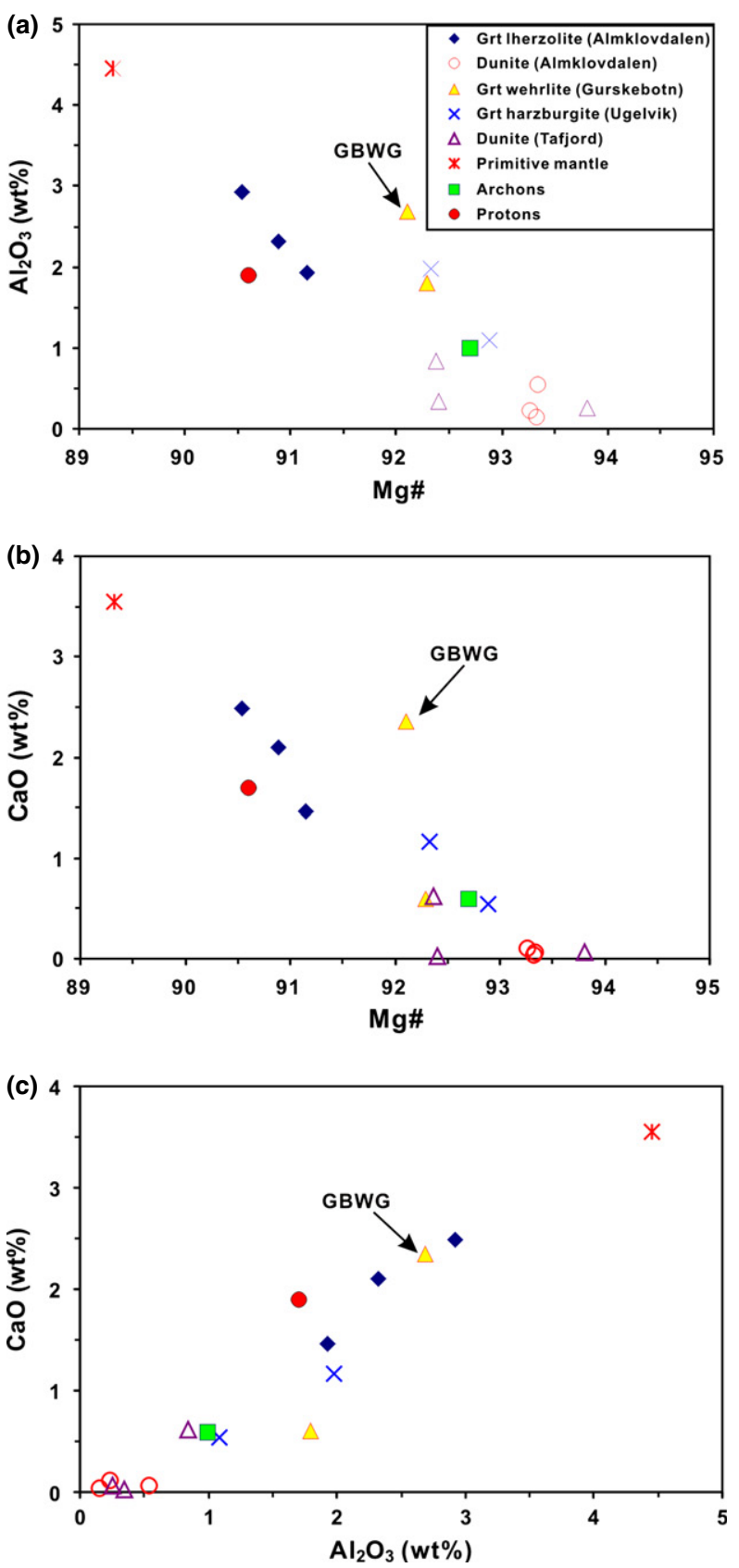

Fig. 3. Correlation of whole-rock $\mathrm{Al}_{2} \mathrm{O}_{3}$ and $\mathrm{CaO}$ abundances with $\mathrm{Mg \#}$ of the peridotites. The compositions of the primitive mantle are from McDonough \& Sun (1995), and mean Archon and Proton subcontinental lithospheric mantle from Griffin et al. (2003).

\section{CRYSTALLOGRAPHIC PREFERRED ORIENTATION}

\section{CPO of olivine}

Our peridotite samples show very different microstructures, ranging from granoblastic, porphyroclastic to mylonitic. To compare the olivine fabrics of bulk 


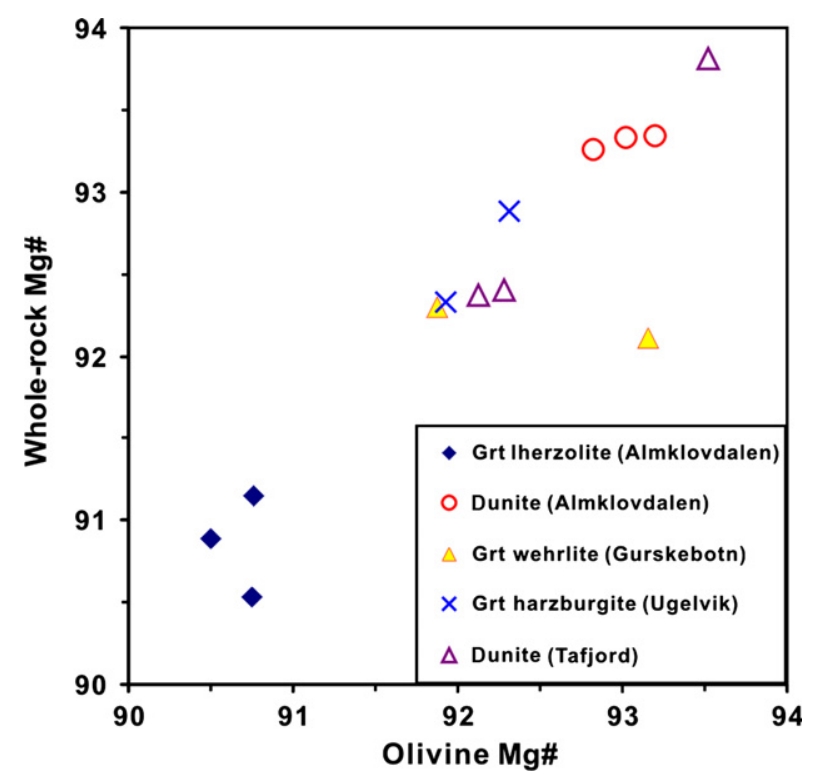

Fig. 4. The whole-rock $\mathrm{Mg} \#$ v. olivine $\mathrm{Mg} \#$ in the peridotites.

samples, porphyroclasts and recrystallized grains, a different step size was used in the EBSD analysis and derived subsets of (i) one point per grain; (ii) coarse grains only; and (iii) small grains only from the complete data set. The technical details for EBSD analysis are given in Appendix S1. Except for garnet wehrlite N97-30 and dunite K-i-I, the pole figures of olivine from the complete data set are consistent with those from different subsets (Table 2, Figs 5 \& 6, S1 \& S2). In addition, fabrics of locally recrystallized small grains were studied using a step size of $10 \mu \mathrm{m}$ (Fig. S1). The local CPO of recrystallized grains may be strongly influenced by the crystallographic orientation of the host grains, as indicated by core-andmantle structures in mylonite $\mathrm{K}-\mathrm{i}-\mathrm{I}$ and protomylonite GBWG. Such a phenomenon has been observed in the Balmuccia peridotite complex from the Western Alps (Matysiak \& Trepmann, 2012) and in deformation and recrystallization experiments on natural peridotites (Druiventak et al., 2012).

The garnet lherzolites and dunites in Almklovdalen show three types of olivine CPO (Fig. 5). Garnet lherzolites N97-5 and N97-18, and dunite N97-9 developed [001](010) fabric (B-type) characterized by the concentration of [001] axes subparallel to the lineation and [010] axes normal to the foliation. Dunites N97-8 and N97-13 show a preferential alignment of [100] axes of olivine parallel to the lineation and [010] axes normal to the foliation, which is the most common [100](010) fabric (A-type) of olivine in the upper mantle (Ben Ismaïl \& Mainprice, 1998). However, garnet lherzolite N97-14 has the E-type fabric defined by the point maxima of [100] axes subparallel to the lineation and [001] axes normal to the foliation.

As shown in Fig. 6, olivine in garnet harzburgites N97-40 and N97-41 from Ugelvik forms the [001](100)

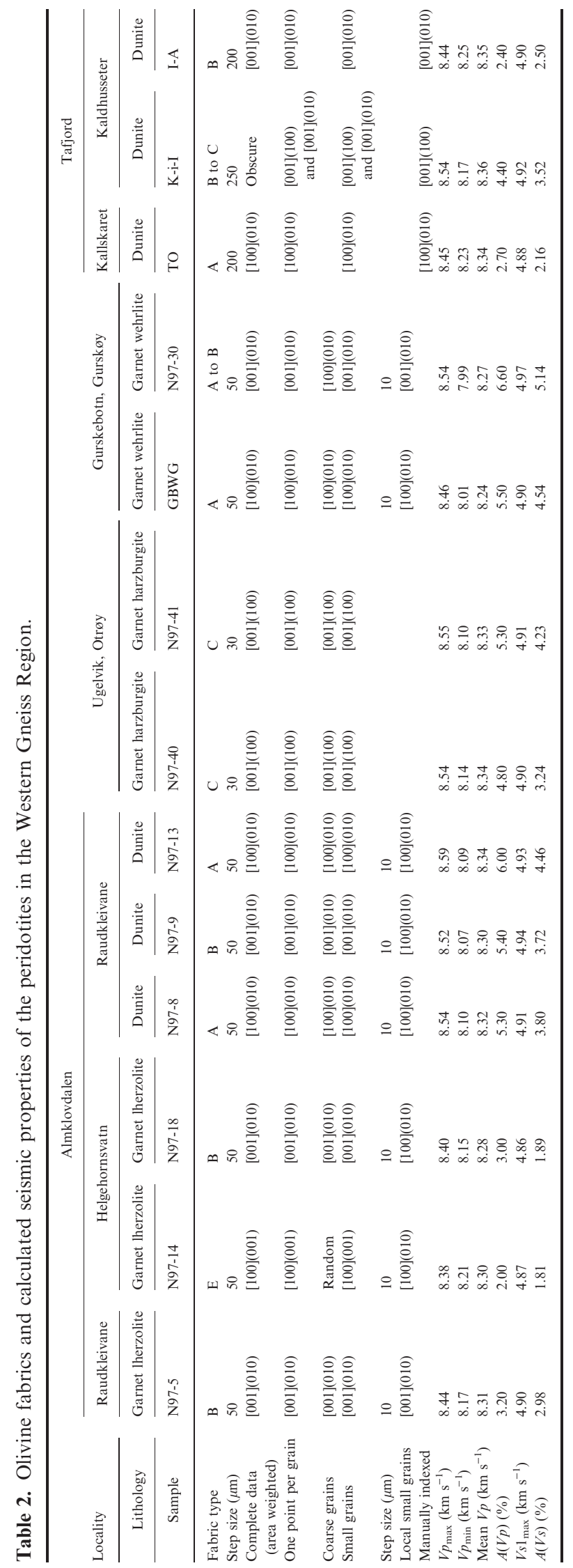




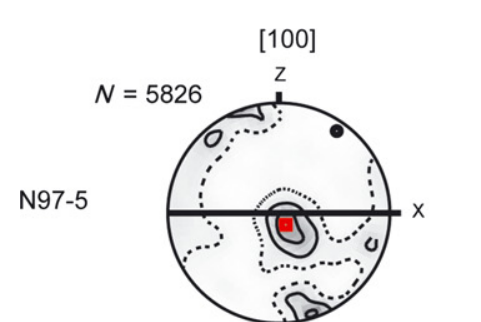

nax. Den. $=3.52 \bullet \operatorname{Min}$. Den. $=0.13$ $\mathrm{pfJ}=1.42$
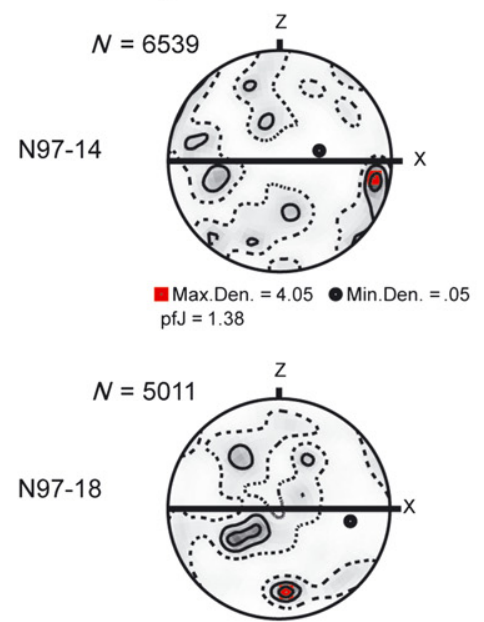

max.Den. $=3.69 \bullet$ Min. Den. $=0.20$ pfJ $=1.33$

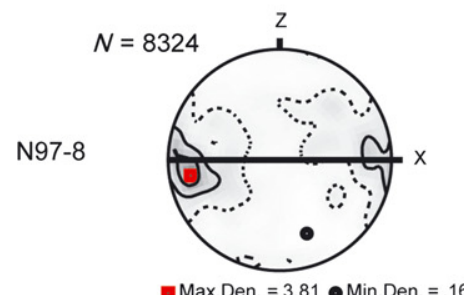
pfJ $=1.38$

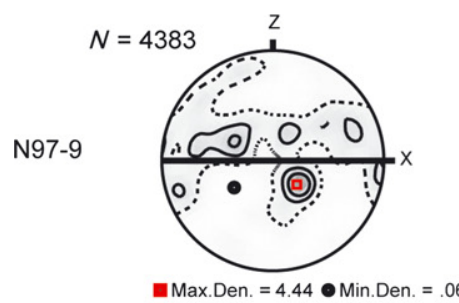

Max. Den. $=4.44 \bullet$ Min.Den. $=.06$ $\mathrm{pfJ}=1.50$

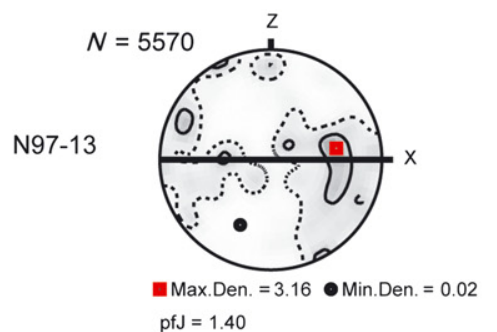

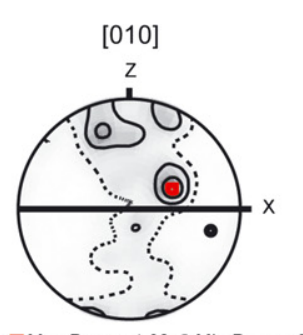

max.Den. $=4.02 \bullet$ Min.Den. $=0.13$ $\mathrm{pfJ}=1.52$

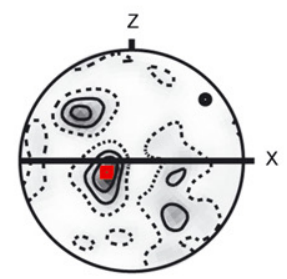

-Max.Den. $=4.14 \bullet$ Min. Den. $=11$ $\mathrm{pfJ}=1.46$

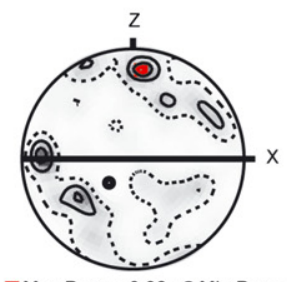

ax.Den. $=3.96 \bullet$ Min.Den. $=0.18$ $\mathrm{pfJ}=1.37$
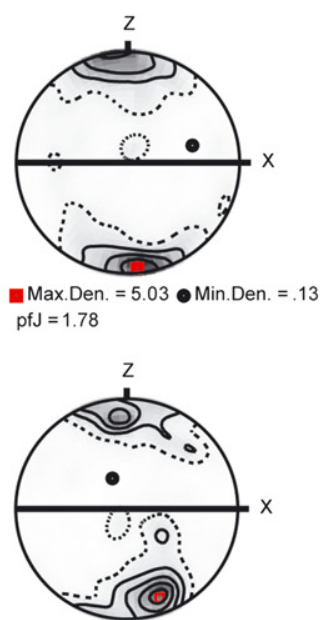

Max.Den. $=5.66 \bullet$ Min. Den. $=.04$ $\mathrm{pfJ}=2.15$

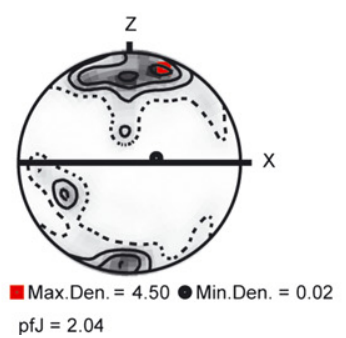

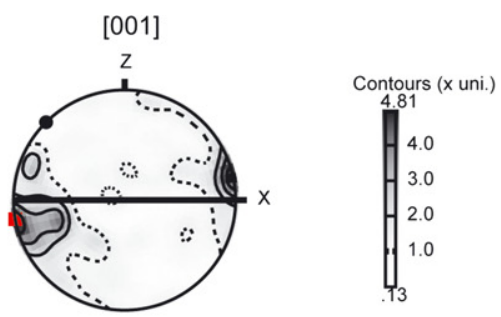

- Max.Den. $=4.81 \bullet$ Min.Den. $=0.20$ $\mathrm{pfJ}=1.58$

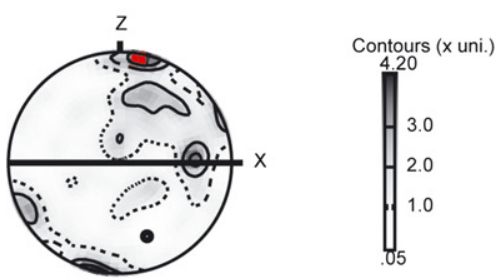

Max.Den. $=4.20 \bullet$ Min.Den. $=.09$ $\mathrm{pfJ}=1.48$
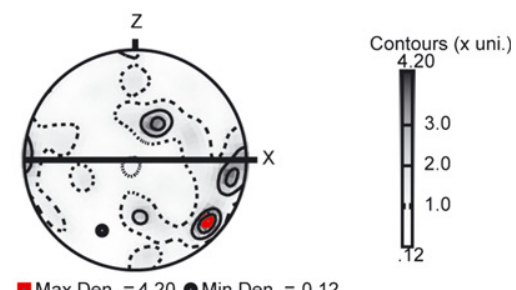

Max.Den. $=4.20 \bullet$ Min. Den. $=0.12$ pfJ $=1.37$
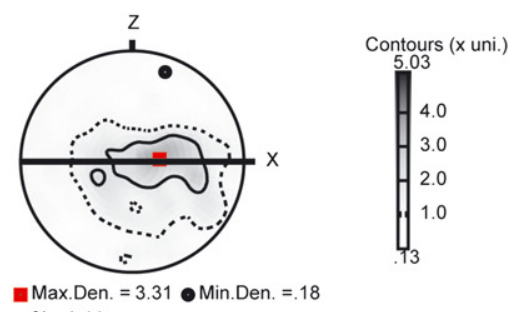

pfJ $=1.44$
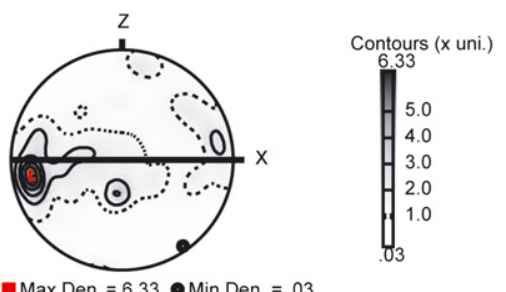

$\mathrm{pfJ}=1.67$

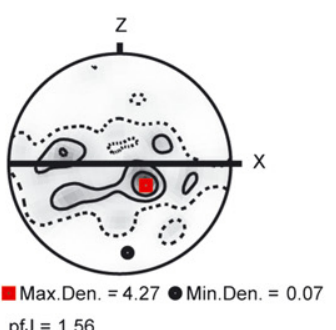

Fig. 5. Electron backscatter diffraction-measured crystallographic preferred orientation of olivine using the complete data set (area weighted) for the peridotites from Almklovdalen. Equal-area projection, lower hemisphere. The contours at multiples of a uniform distribution are plotted and an inverse log grey scale is used to emphasize high densities. Structural directions $X, Y$ and $Z$ are defined in the text. $N$, number of data points; pfJ, texture index. 


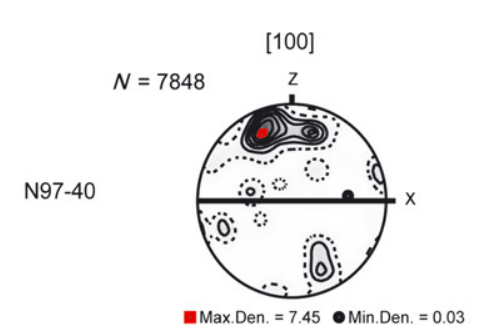

max.Den. $=7.45 \bullet$ Min. Den. $=0.03$ $\mathrm{pfJ}=2.35$

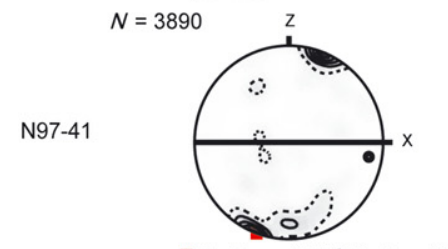

Max.Den. $=11.00 \bullet$ Min.Den. $=0.04$ $\mathrm{pfJ}=2.68$

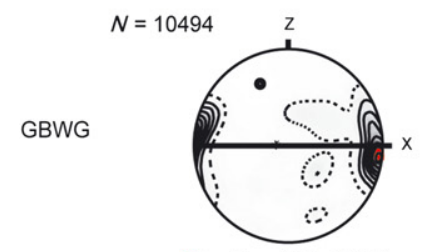

amax.Den. $=8.79 \bullet$ Min.Den. $=0.11$ $\mathrm{pf} f=2.39$

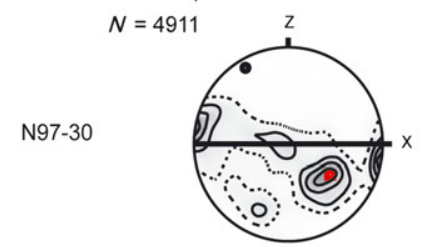

amax.Den. $=4.68 \bullet$ Min.Den. $=0.04$ $\mathrm{pfJ}=1.83$

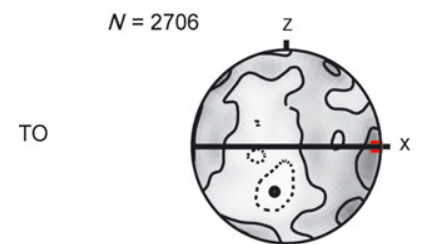

-Max.Den. $=1.87 \bullet$ Min. Den. $=0.34$ $\mathrm{pfJ}=1.11$

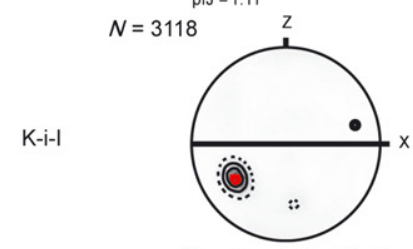

max.Den. $=8.52 \bullet$ Min.Den. $=0.39$ $\mathrm{pfJ}=1.74$

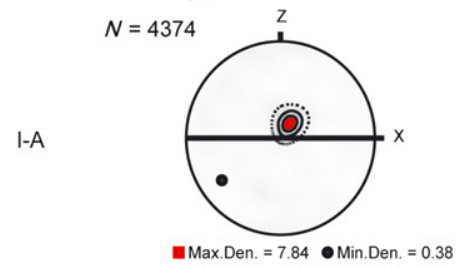
$\mathrm{pfJ}=1.56$
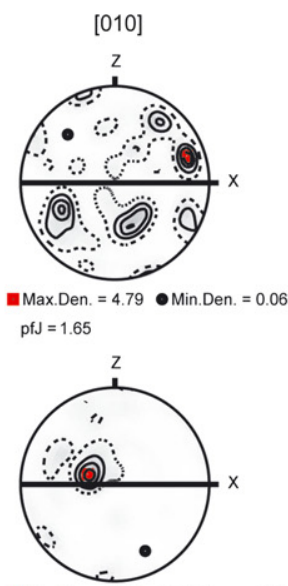

- Max.Den. $=9.28 \bullet$ Min.Den. $=0.04$ $\mathrm{pfJ}=2.31$

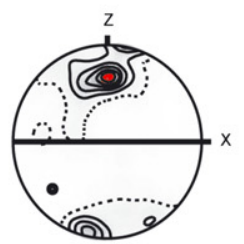

- Max. Den. $=7.29 \bullet$ Min. Den. $=0.13$ $\mathrm{pfJ}=2.05$

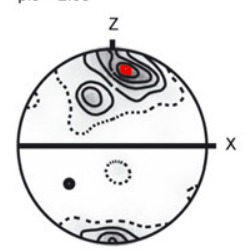

a Max.Den. $=6.30 \bullet$ Min.Den. $=0.06$ $\mathrm{pfJ}=2.18$

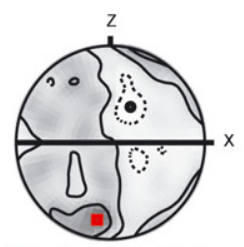

- Max.Den. $=2.03 \bullet$ Min.Den. $=0.23$ $\mathrm{pfJ}=1.11$

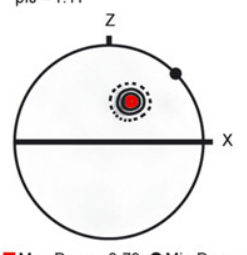

Max. Den. $=8.79 \bullet$ Min. Den. $=0.32$ pfJ $=1.70$

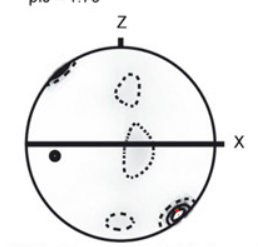

-Max.Den. $=8.00$ Min.Den. $=0.15$ $\mathrm{pfJ}=1.77$

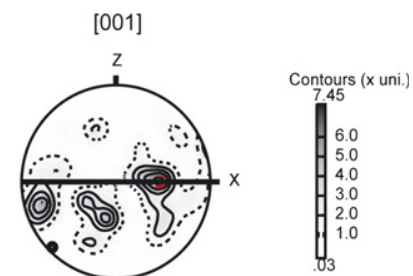

- Max.Den.$=5.54$ Min.Den. $=0.08$

$\mathrm{pfJ}=1.92$

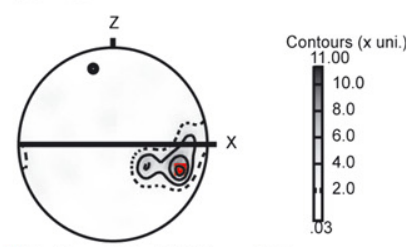

EMax.Den $=9.03$ Min.Den. $=0.03$

pfJ $=2.76$

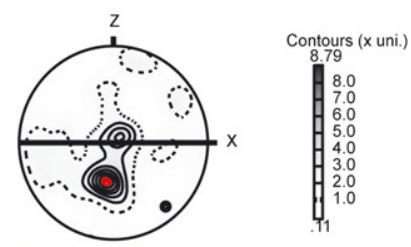

-Max.Den. $=7.42 \bullet$ Min. Den. $=0.14$

$\mathrm{pfJ}=1.80$

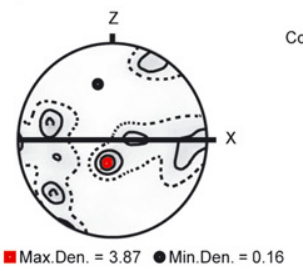

$\mathrm{pfJ}=1.48$

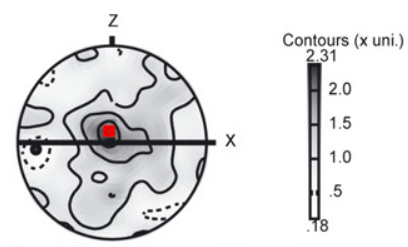

nax.Den. $=2.31 \bullet$ Min.Den. $=0.18$

$\mathrm{pfJ}=1.12$

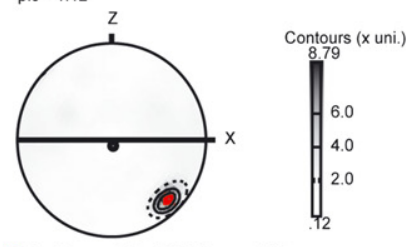

Max.Den. $=8.79 \bullet$ Min. Den. $=0.12$ $p f J=1.73$

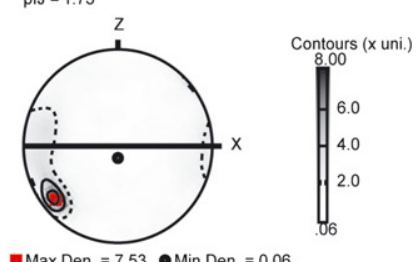

-Max.Den. $=7.53 \bullet$ Min.Den. $=0.06$ $\mathrm{pfJ}=1.90$

Fig. 6 Electron backscatter diffraction-measured crystallographic preferred orientation of olivine for the peridotites from Gurskøy, Otrøy and the Tafjord area. Description is same as in Fig. 5. 
fabric (C-type), which is defined by the concentration of [001] axes parallel to the lineation and [100] axes normal to the foliation. For garnet wehrlites from Gurskebotn, the complete data sets of olivine yield the typical $[100](010)$ fabric in GBWG, but [001](010) fabric in N97-30. In addition, the pole figures of sample N97-30 reveal [001](010) fabric for the subsets of one point per grain, small grains $(<150 \mu \mathrm{m})$ and locally recrystallized small grains, but $[100](010)$ fabric for a subset of coarse grains $(>300 \mu \mathrm{m}$; Fig. S2). Combined with the porphyroclastic texture in thin section, protomylonite N97-30 may record a gradual transition from the A-type fabric in porphyroclasts to the B-type fabric in recrystallized grains during shearing.

For the two dunites from Kallskaret in the Tafjord area, sample TO with granoblastic texture displays a very weak A-type fabric. The dunite mylonite K-i-I contains a large $\sigma$-type olivine porphyroclast in thin section (Fig. 2k). Hence, the area-weighted olivine CPO using the complete data set is controlled by the orientation of the large porphyroclast (Fig. S3). However, the subsets of small olivine grains $(<300 \mu \mathrm{m})$ and onepoint-per-grain extracted from the complete data set reveal that the maximum concentration of [001] axes is parallel to the lineation, while [100] and [010] axes form a girdle normal to the lineation with the maximum concentration near the $Z$ direction, implying the activation of both [001](100) and [001](010) slip systems. Manually indexed individual olivine points yield a clear [001](100) fabric. Therefore, the recrystallized olivine grains in mylonite $\mathrm{K}-\mathrm{i}-\mathrm{I}$ were subjected to a fabric transition from the B-type to the C-type. In contrast, olivine in the dunite mylonite I-A from Kaldhusseter shows a typical [001](010) fabric, as do samples N97-5 and N97-9 from the Almklovdalen area.

\section{CPO of enstatite}

The pole figures of enstatite are shown in Figs S4 \& S5. Enstatite in garnet lherzolite N97-5 and dunites TO and I-A exhibits nearly random orientation due to the small number of data points; therefore, they are not discussed further. For all the other samples, the CPO of enstatite is characterized by the concentration of [001] axes subparallel to the lineation and [100] axes normal to the foliation, suggesting the dominant slip system of [001](100) as observed in previous studies (e.g. Mercier, 1985). In Opx-rich rocks N97-40, N9741, GBWG and N97-30, the CPO pattern of enstatite is consistent in fine-grained $(<150 \mu \mathrm{m})$ and coarsegrained $(>300 \mu \mathrm{m})$ subsets.

\section{CPO of diopside}

Due to smaller Burgers vectors in clinopyroxene, there are more active slip systems in clinopyroxene than in orthopyroxene. Diopside from seven garnet peridotite samples displays different fabrics (Fig. S6). In samples
N97-18, GBWG and N97-40, the CPO of diopside is defined by a strong concentration of [001] axes subparallel to the lineation and (010)-poles subnormal to the foliation, which can be explained by activation of multiple dislocation glide on $1 / 2<110>\{\overline{1} 10\}$, $[001]\{110\}$ and [001](100) slip systems (Godard \& Van Roermund, 1995; Bascou et al., 2002). However, diopside in garnet lherzolite N97-14 develops the $[100](010)$ fabric, which is very rare in peridotites. Compared with the strong fabrics of olivine, the $\mathrm{CPO}$ of diopside in samples N97-5, N97-30 and N97-41 is very weak.

\section{SEISMIC ANISOTROPY}

Ignoring minor minerals, such as garnet, chlorite, serpentine and chromite, the seismic velocities and anisotropy of the WGR peridotite were calculated from the CPOs of major minerals using the Hill average and re-adjusted modal compositions, which allow us to investigate the relationships between the CPO, the volume fraction of each constituent mineral, and the overall seismic velocities and anisotropy of polyphase rocks. The complete EBSD mapping data are used in the calculation to give area-weighted physical properties of the bulk samples. The single crystal elastic constants and density are taken from studies on olivine (Abramson et al., 1997), enstatite (Chai et al., 1997) and diopside (Collins \& Brown, 1998). The seismic properties of olivine, enstatite and diopside are provided in Fig. S7. Due to its high seismic velocities and weak anisotropy, garnet will increase the seismic velocities and decrease the seismic anisotropy of rocks, but will not affect the seismic anisotropy pattern (Mainprice et al., 2004; Wang et al., 2009). The alteration minerals such as serpentine, chlorite, tremolite and phlogopite were formed during exhumation of the peridotites to the middle and upper crust; therefore, they can be ignored when modelling the in-situ composition.

Figures 7 and 8 present the $\mathrm{P}$ - and $\mathrm{S}$-wave velocities, anisotropy and shear wave splitting of 13 peridotite samples. The $V p$ anisotropy, $A(V p)$, is defined as $A(V p)=\left(V p_{\max }-V p_{\min }\right) /\left(V p_{\max }+V p_{\min }\right) \times 2 \times$ $100 \%$, where $V p_{\max }$ and $V p_{\min }$ are the fastest and slowest velocity of the sample, respectively. Thus, $A(V p)$ is direction independent and only reflects the relative difference between $V p_{\max }$ and $V p_{\min }$. The values of $A(V p)$ in our samples vary between 2.2 and $6.6 \%$, with the mean $V p$ between 8.24 and $8.36 \mathrm{~km} \mathrm{~s}^{-1}$ (Table 2). Shear wave splitting will occur in an anisotropic solid. The $V S$ anisotropy along the propagation direction in question, $A(V s)$, is defined as $(V s 1-V s 2) /(V s 1+V s 2)$ $\times 2 \times 100 \%$, where $V s 1$ and $V s 2$ are the fast and slow $\mathrm{S}$ wave velocities with mutually orthogonal polarizations. So $A(V s)$ is a directional parameter and relates with the shear wave splitting $\left(V_{s} 1-V_{s} 2\right)$. The values of the maximum $A(V s)$ for our samples are in the range of 1.8$5.1 \%$ (Table 2). 


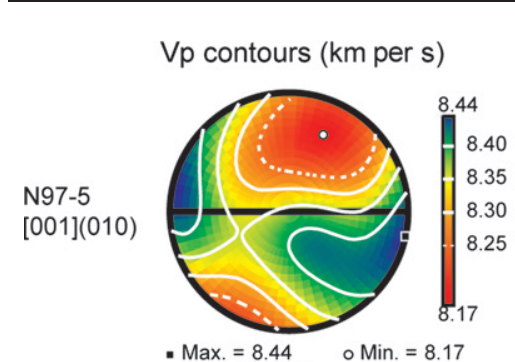

$\begin{aligned} \text { - Max. } & =8.44 \\ \text { Anis. } & =3.2 \%\end{aligned}$ o Min. $=8.17$

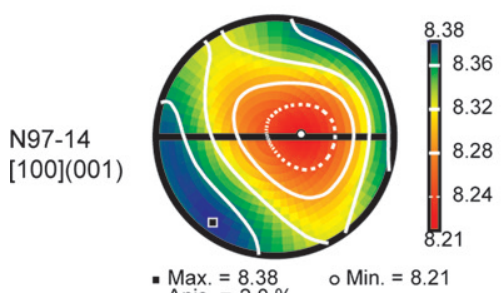

- Max. $=8.38$
Anis. $=2.0 \%$

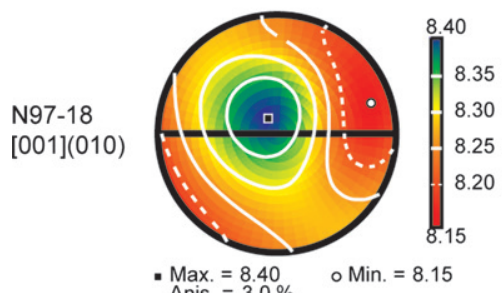

$\begin{aligned} \text { - Max. } & =8.40 \\ \text { Anis. } & =3.0 \%\end{aligned}$
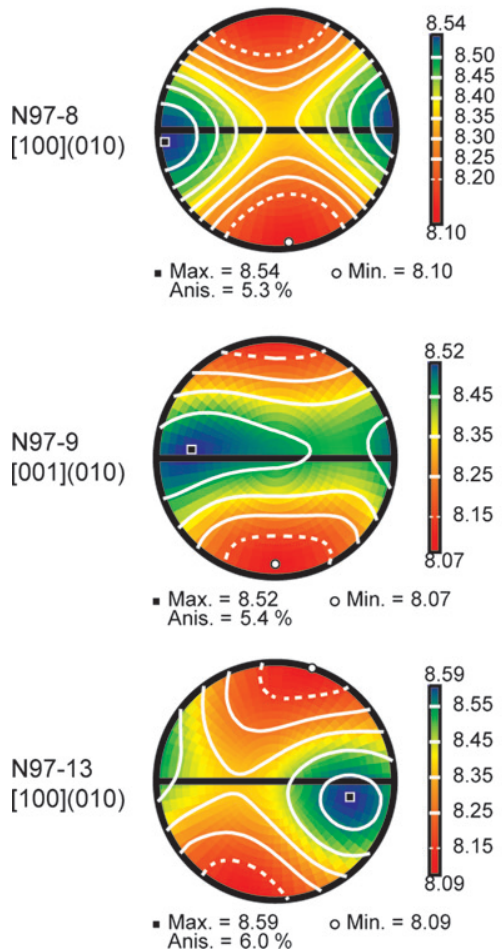

Vs1 contours (km per s)

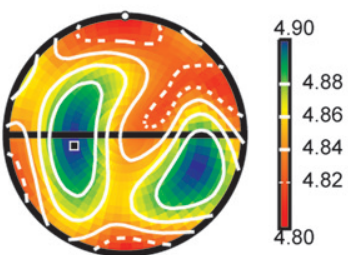

$\begin{aligned} \text { - Max. } & =4.90 \\ \text { Anis. } & =2.2 \%\end{aligned}$ ○ Min. $=4.80$

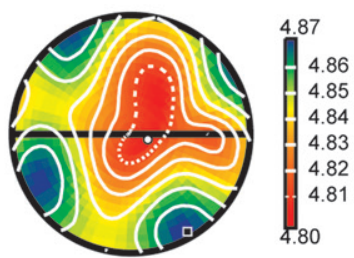

- Max. $=4.87 \quad$ o Min. $=4.80$ Anis. $=1.4 \%$

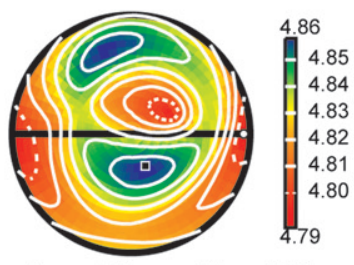

- Max. $=4.86 \quad$ o Min. $=4.79$

Anis. $=1.4 \%$

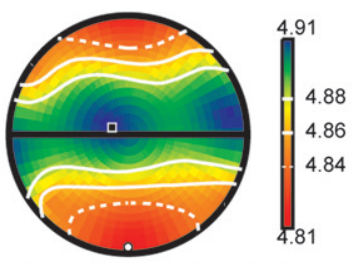

- Max. $=4.91 \quad$ o Min. $=4.81$

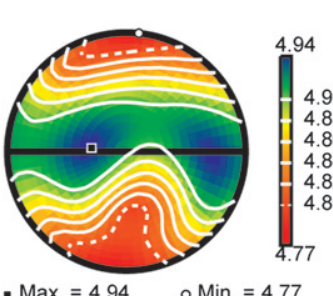

$\begin{aligned} \text { - Max. } & =4.94 \% \text { o Min. }=4.77 \\ \text { Anis. } & =3.5 \%\end{aligned}$

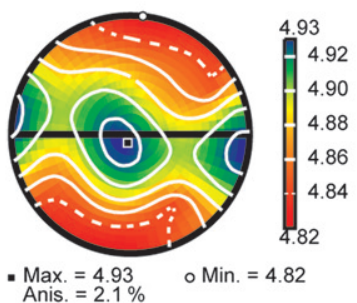

AVs contours (\%)

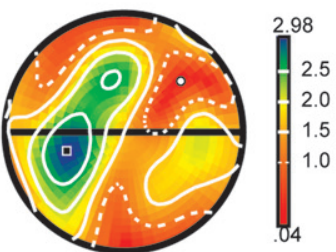

- Max.Anis. $=2.98 \circ$ Min.Anis. $=.04$

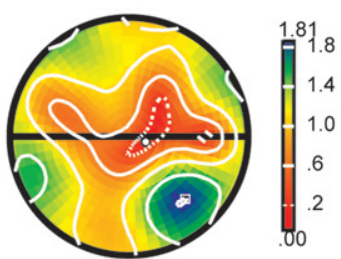

- Max.Anis. $=1.81 \circ$ Min. Anis $=00$

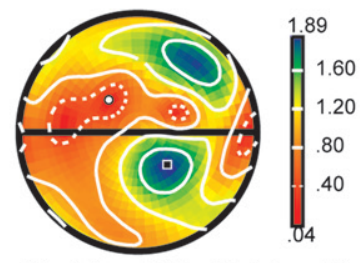

- Max.Anis. $=1.89 \circ$ Min.Anis. $=.04$
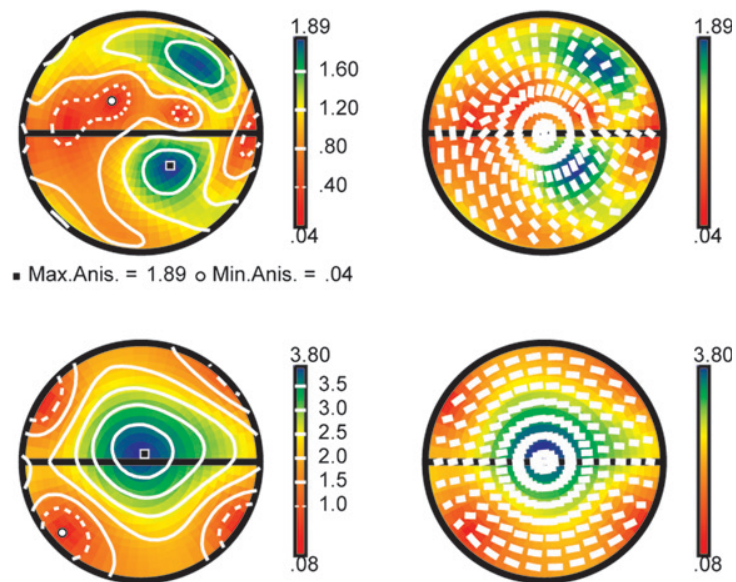

- Max.Anis. $=3.80 \circ$ Min.Anis. $=.08$
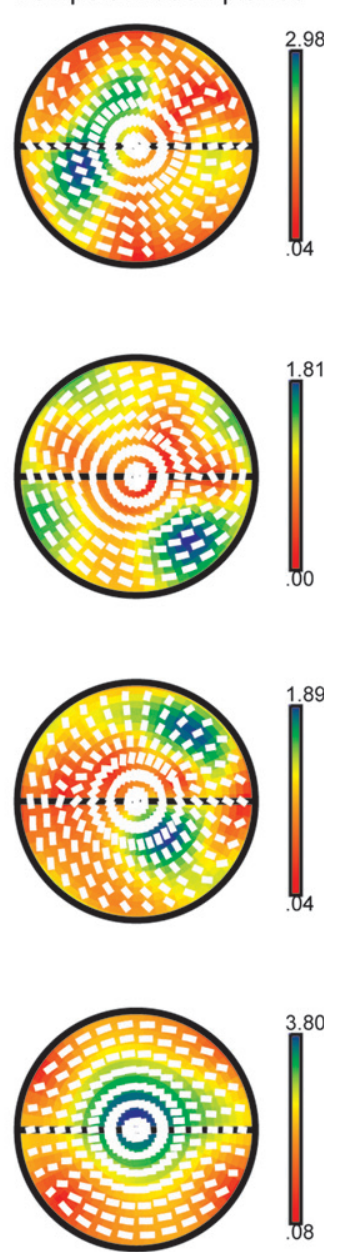

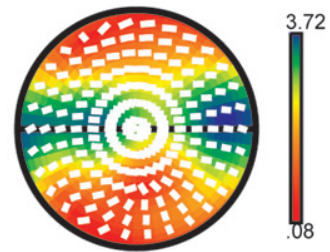

- Max.Anis. $=3.72 \circ$ Min. Anis. $=.08$
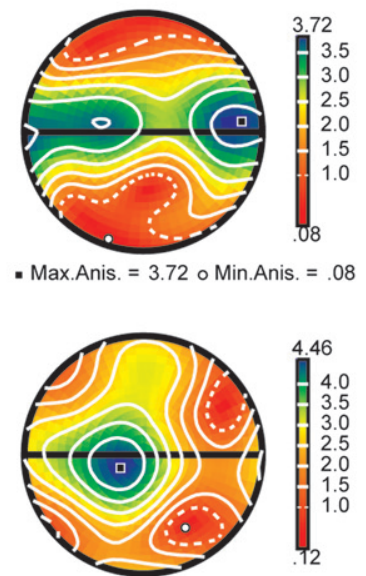

- Max.Anis. $=4.46 \circ$ Min.Anis. $=.12$

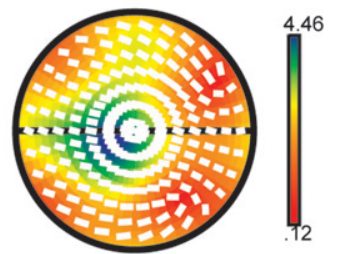

Fig. 7. Calculated P- and S-wave seismic properties of the Almklovdalen peridotites. Equal-area projection, lower hemisphere. Structural directions $X, Y$ and $Z$ are defined in the text.

Olivine has an orthorhombic symmetry with $V p_{\max }$ and $V p_{\min }$ propagating along the [100] and [010] axis, respectively, and the maximum $V s 1$ along the [101] direction (Fig. S7a). Because olivine is volumetrically dominant, $V p_{\max }$ and $V p_{\min }$ of peridotites are controlled by the orientation of olivine [100] and [010] 


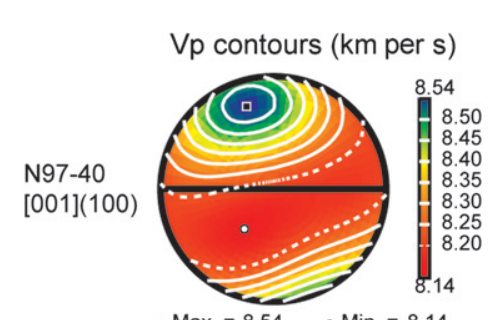

$\begin{aligned} & \text { - Max. }=8.54 \\ & \text { Anis. }=4.8 \%\end{aligned} \quad \circ$ Min. $=8.14$

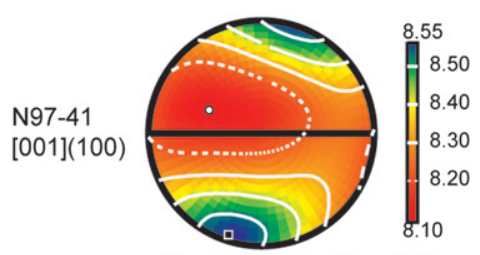

- Max. $=8.55$
Anis. $=5.3 \%$ ○ Min. $=8.10$

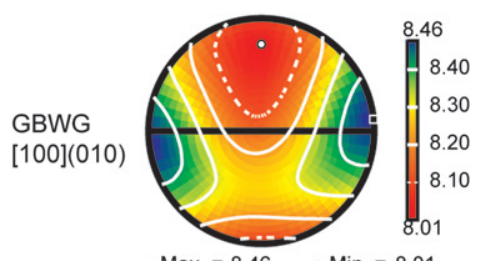

$\begin{aligned} \text { - Max. } & =8.46 \% \text { ○ Min. }=8.01 \\ \text { Anis. } & =5.5 \%\end{aligned}$
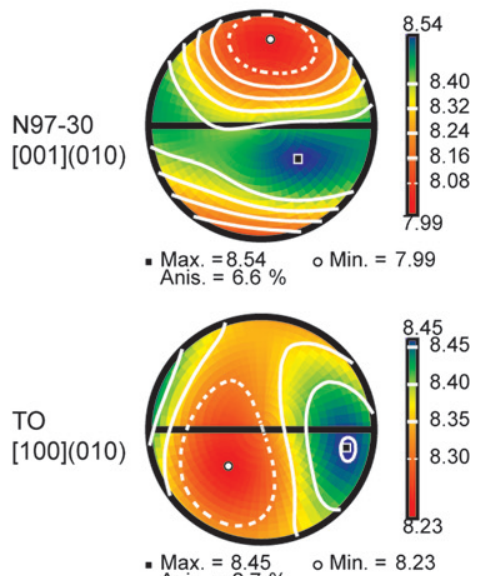

- Max. $=8.45 \%$ o Min. $=8.23$

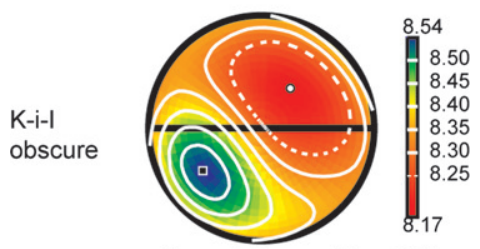

$\begin{aligned} \text { - Max. } & =8.54 \\ \text { Anis. } & =4.4 \%\end{aligned}$ ○Min. $=8.17$

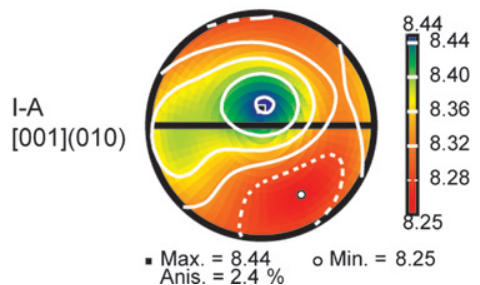

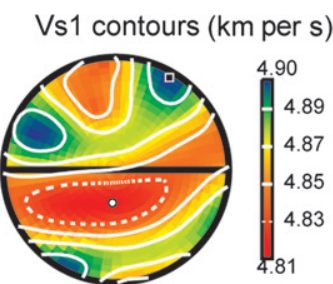

- Max. $=4.90 \quad$ oMin. $=4.81$

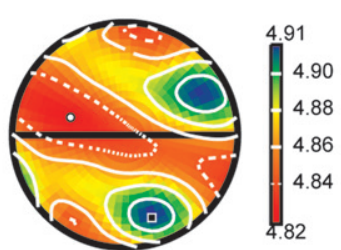

- Max. $=4.91$
Anis. $=1.9 \%$ ○Min. $=4.82$

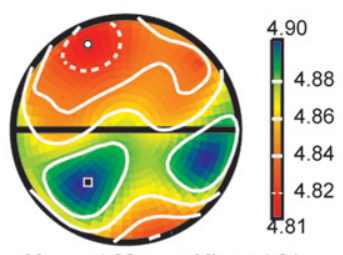

$\begin{aligned} \text { - Max. } & =4.90 \\ \text { Anis. } & =1.9 \%\end{aligned}$

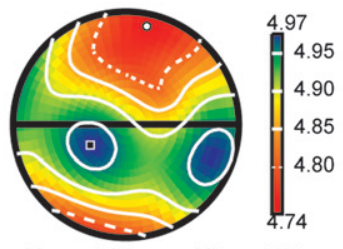

- Max. $=4.97 \%$ ○ Min. $=4.74$

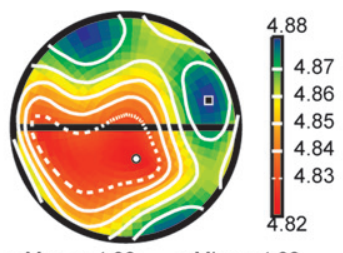

- Max. $=4.88 \quad$ o Min. $=4.82$

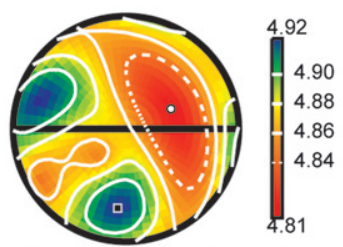

$\begin{aligned} & \text { - Max. }=4.92 \% \text { o Min. }=4.81 \\ & \text { Anis. }=2.4 \%\end{aligned}$

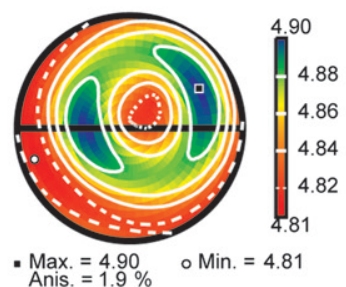

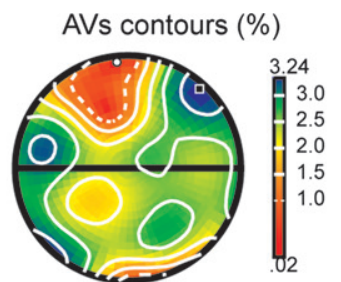

- Max.Anis. = 3.24 ○ Min.Anis. $=.02$

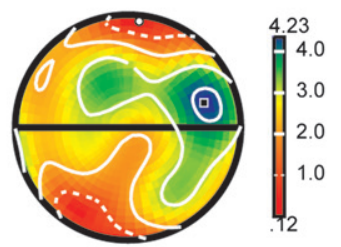

- Max.Anis. $=4.23 \circ$ Min.Anis. $=.12$

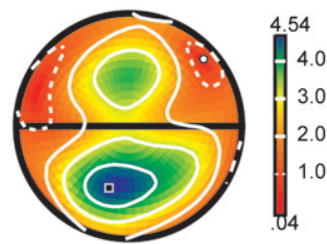

- Max.Anis. $=4.54 \circ$ Min.Anis $=.04$

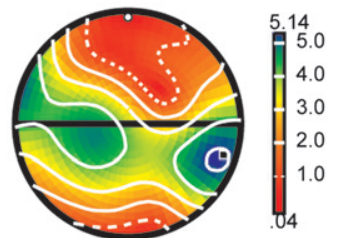

- Max.Anis. $=5.14 \circ$ Min.Anis. $=.04$
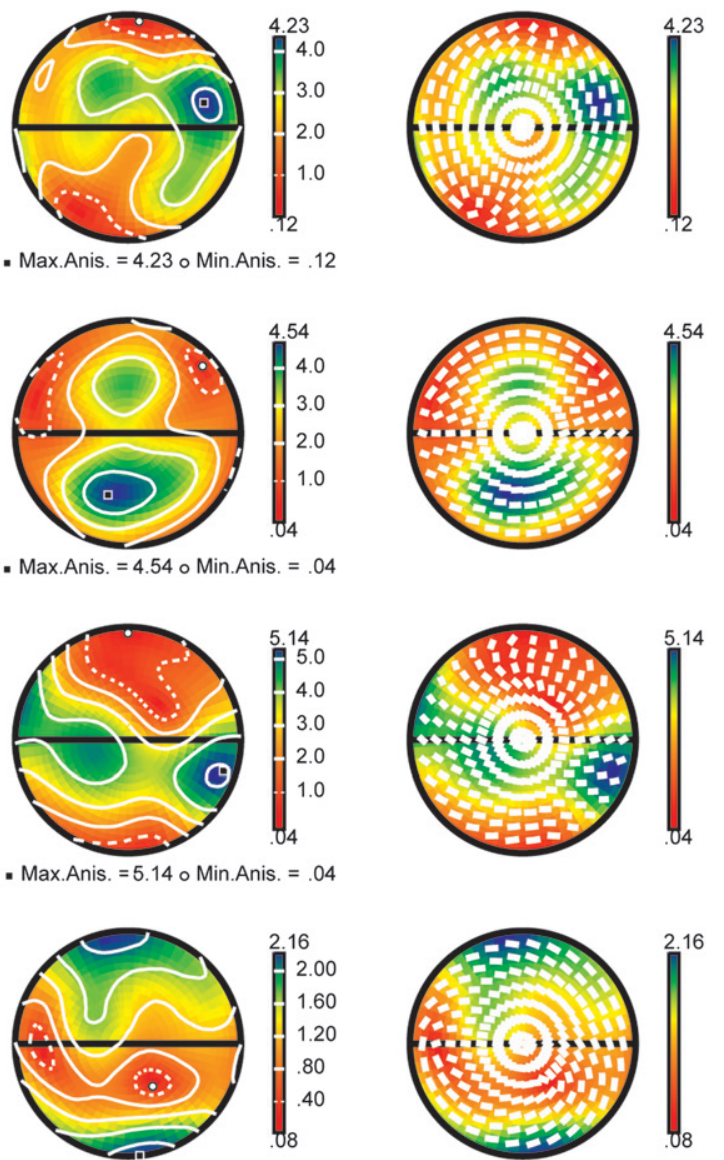

- Max.Anis. $=2.16 \circ$ Min.Anis. $=.08$
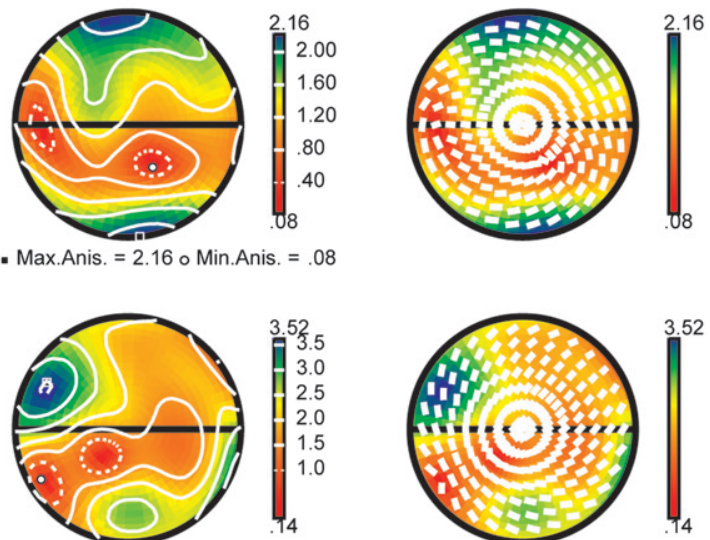

- Max.Anis. $=3.52 \circ$ Min.Anis. $=.14$
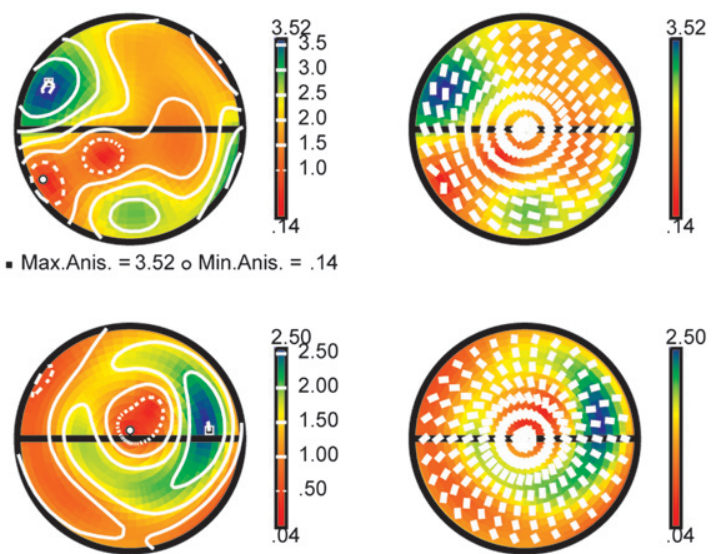

- Max.Anis. $=2.50 \circ$ Min.Anis. $=.04$

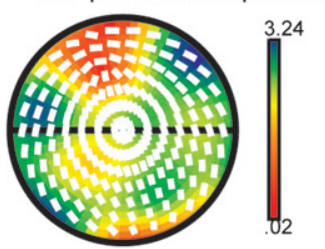

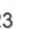

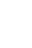

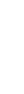


axes, respectively. The seismic anisotropy of our samples shows a good correlation with olivine fabrics. The stronger the fabric strength of olivine, as indicated by the pfJ values in Figs $5 \&$ 6, the higher the anisotropy. However, because enstatite has a similar seismic anisotropy pattern to olivine (Fig. S7b) and generally develops [001](100) fabric (Figs S4 \& S5), if olivine does not form the same fabric (C-type), the enstatite $\mathrm{CPO}$ will decrease the value of seismic anisotropy, and even change the propagation direction of $V p_{\max }, V p_{\min }$ and $V_{S} 1$ in Opx-rich rocks.

Four samples N97-8, N97-13, GBWG and TO show $V p_{\text {max }}$ subparallel to the lineation and $V p_{\min }$ normal to the foliation, and the polarization plane of the fastest $\mathrm{S}$-wave subparallel to the foliation, which is consistent with their [100](010) olivine fabric. The maximum shear wave splitting is parallel to the $Y$ structural direction in dunites N97-8 and N97-13, but becomes normal to the foliation in samples GBWG and TO.

Five samples with the B-type olivine fabric (N97-5, N97-18, N97-9, N97-30 \& I-A) are strongly sheared garnet lherzolites and dunites. Except for garnet lherzolite N97-18, the polarization plane of the fastest $\mathrm{S}$-wave is subparallel to the foliation. For samples N97-18, N97-30 and I-A, $V p_{\max }$ is subparallel to the $Y$ direction and $V p_{\min }$ is subnormal to the foliation, consistent with their [001](010) olivine fabric. However, samples N97-5 and N97-9 show $V p_{\max }$ subparallel to the lineation and $V p_{\min }$ normal to the foliation, which is similar to the seismic anisotropy of peridotites with the A-type olivine fabric. The calculated seismic properties of $100 \%$ olivine aggregates using the olivine CPO of samples N97-5 and N97-9 indicate that this discrepancy is caused by the preferred orientation of olivine [100] axes (Fig. S8), which forms a girdle subparallel to the foliation instead of a point maximum along the $Y$ direction. Therefore, the transition from the A-type to the B-type olivine fabric may be not recognizable in seismic anisotropy observations.

Garnet harzburgites N97-40 and N97-41 from Ugelvik yield the C-type olivine fabric. As a result, $V p_{\text {max }}$ is normal to the foliation and $V p_{\text {min }}$ is parallel to the $Y$ direction, with $A(V p)$ of $4.8-5.3 \%$. The $V_{S} 1$ polarization plane is generally normal to the foliation. In dunite $\mathrm{K}-\mathrm{i}-\mathrm{I}$, a large olivine porphyroclast obscured the fabric of recrystallized grains (Fig. S3), and the area-weighted seismic anisotropy of the bulk sample is controlled by the orientation of the porphyroclast. Compared with samples N97-40 and N97-41, garnet lherzolite N97-14 with the E-type fabric exhibits a similar seismic anisotropy pattern but much lower $A(V p)$. The calculated seismic properties of $100 \%$ olivine and $100 \%$ enstatite aggregates using the CPO data of sample N97-14 indicate that the olivine [100](001) fabric will produce $V p_{\max }$ parallel to the lineation and $V p_{\min }$ parallel to the $Y$ direction, while the enstatite [001](100) fabric will result in $V p_{\max }$ normal to the foliation and $V p_{\text {min }}$ parallel to the $Y$ direction (Fig. S8). Thus, the seismic anisotropy of sample N97-14 is characterized by $V p_{\max }$ normal to the foliation, and $V p_{\min }$ parallel to $Y$ direction. Clearly, more attention is needed to distinguish the $\mathrm{C}$ - and E-type fabrics of olivine from seismic anisotropy, especially for pyroxene-rich rocks.

\section{WATER CONTENTS OF OLIVINE}

Water contents of coarse-grained and fine-grained olivine were measured by Fourier transform infrared (FTIR) analysis (Appendix S1). Figure 9 shows typical unpolarized FTIR spectra of olivine. The absorption bands in the range of $3500-3570 \mathrm{~cm}^{-1}$ represent structural hydroxyl species in olivine, while peaks near 3690 and $3645 \mathrm{~cm}^{-1}$ correspond to the $\mathrm{OH}$ stretching bands of serpentine, and a broad absorption near $3410 \mathrm{~cm}^{-1}$ may reflect submicroscopic fluid inclusions in olivine (e.g. Miller et al., 1987; Khisina et al., 2001; Kovacs et al., 2008). The characteristic peaks of serpentine at 3690 and $3645 \mathrm{~cm}^{-1}$ are common in most samples, which can be attributed to serpentine along microcracks in olivine. In the moderately serpentinized sample N9740 , all the analysed grains display characteristic peaks of serpentine, which hampered estimation of its $\mathrm{OH}$ concentration. Excluding the altered grains with serpentine and fluid inclusions, no peak of structural hydroxyl species was observed in dunite TO, suggesting that its $\mathrm{OH}$ concentration is less than the detection limit of the FTIR spectroscopy $\left(\sim 1 \mathrm{ppm} \mathrm{H}_{2} \mathrm{O}\right)$. Only the spectra with the dominant peak near $3570 \mathrm{~cm}^{-1}$ were selected for the calculation of water contents using a recent calibration (Bell et al., 2003). Our results are $\sim 3.5$ times the values derived from the Paterson (1982) calibration, which has been widely used in water content analysis of olivine (e.g. Katayama et al., 2005; Xu et al., 2006; Wang, 2010). In order to compare with previous studies, our data were divided by a factor of 3.5 (Table 3 ).

Our FTIR analysis demonstrates that both porphyroclasts and recrystallized grains of olivine are very dry. The average water contents of olivine are in the

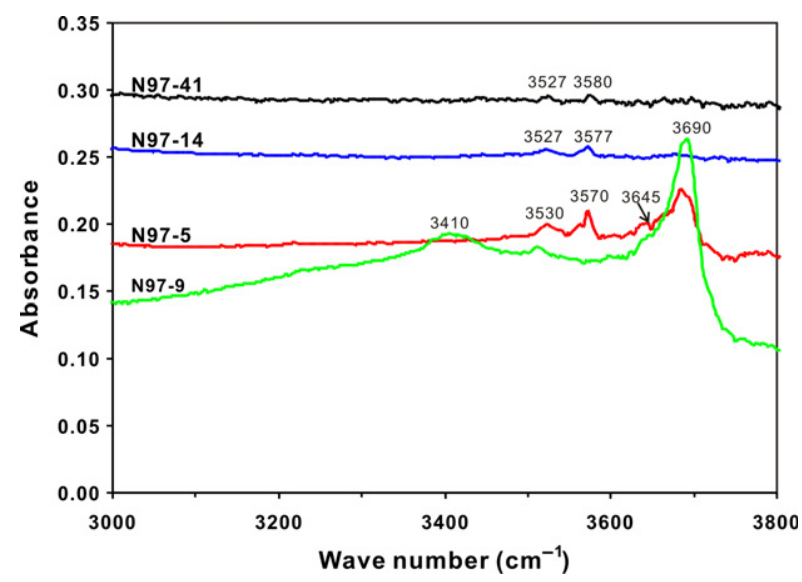

Fig. 9. Typical unpolarized Fourier transform infrared spectra of olivine in the garnet peridotites and dunites. 


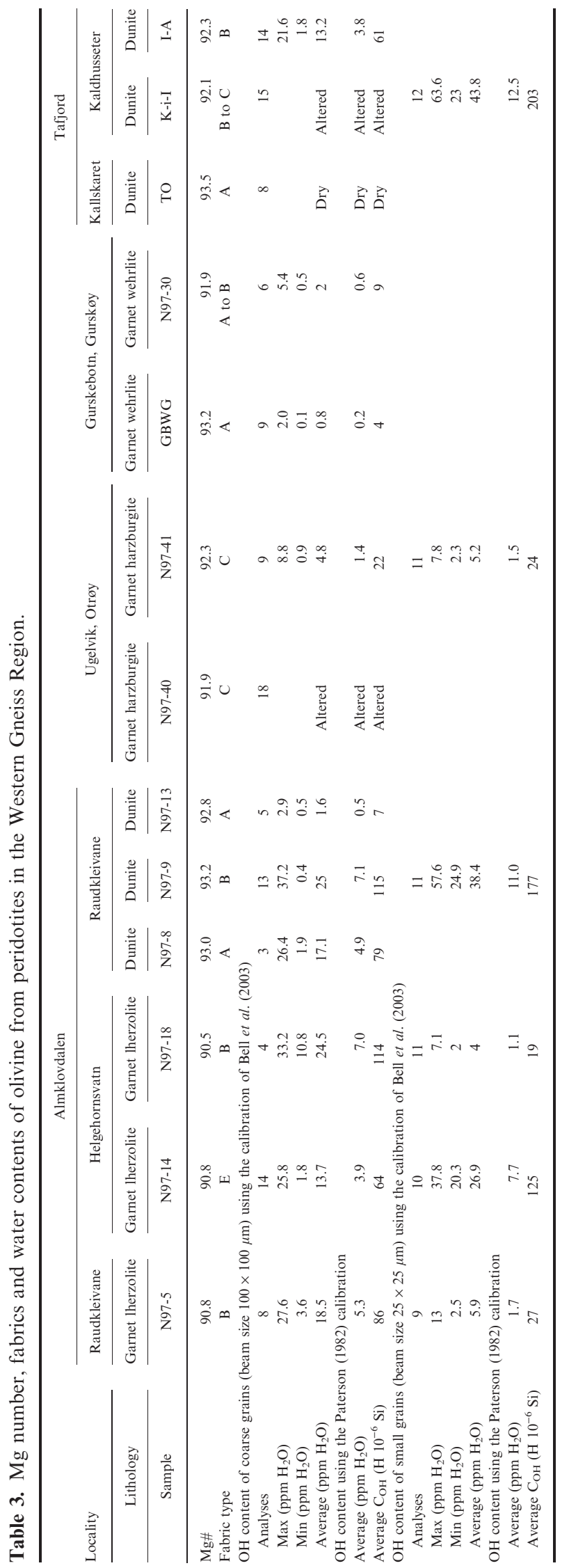

range of $<1-13$ ppm $\mathrm{H}_{2} \mathrm{O}$ using the Paterson (1982) calibration. Coarse olivine grains from dunites N97-13 and TO, and garnet wehrlites GBWG and N97-30 are extremely dry $\left(<1 \mathrm{ppm} \mathrm{H}_{2} \mathrm{O}\right)$. The maximum value of $13 \mathrm{ppm} \mathrm{H}_{2} \mathrm{O}$ is obtained in small grains of dunite mylonite $\mathrm{K}$-i-I, implying a relatively high water fugacity during recrystallization. Given the uncertainty $(<30 \%)$ in the FTIR analysis and the heterogeneous water distribution of water in thin sections, there is no difference between recrystallized and porphyroclastic olivine in sample N97-41. The small differences between the recrystallized olivine grains and olivine porphyroclasts in samples N97-5, N97-14, N97-18 and N97-9 are also negligible.

\section{DISCUSSION}

\section{In situ water contents in olivine}

Katayama et al. (2005) found the C-type fabric in a massive peridotite and the A-type fabric in a layered peridotite with compositional banding of $\mathrm{Cr}$-diopside and garnet from Otrøy. Olivine in both samples is 'wet' (700-800 $\left.\mathrm{H} 10^{-6} \mathrm{Si}\right)$ and shows a dominant slip system of [100](001) (E-type) in dislocation observations. The authors did not provide FTIR spectra of olivine, but claimed that the water contents of these rocks have been modified by extensive hydration and overprinting at amphibolite facies conditions during exhumation. They attributed the C-type olivine fabric to deformation at high water content, low stress ( 10 MPa), HP $(\sim 6 \mathrm{GPa})$ and modest temperature $(\sim 1300 \mathrm{~K})$, and the E-type dislocation microstructures in the two rocks to later deformation at a higher stress level with a moderate water content.

However, the water contents of olivine from our WGR dunites and garnet peridotites, including garnet

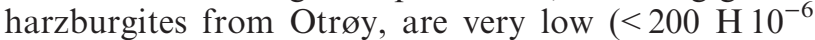
Si) (Table 3). Re-Os dating of peridotites from Nordøyene (Brueckner et al., 2002) and the Almklovdalen and Tafjord areas (Beyer et al., 2004) yielded Archean Re-depletion model ages $\left(t_{\mathrm{RD}} \approx 2.7-3.1 \mathrm{Ga}\right)$ for the dunites, but mixed Archean and Proterozoic wholerock and sulphide ages for the garnet peridotites. The dunites represent the Archean lithospheric mantle residues after $>60 \%$ melt extraction at 5-7 GPa, while the garnet peridotites were formed by metasomatic refertilization of the dunites during the Proterozoic (Beyer et al., 2006). Our samples show a similar strong correlation between whole-rock $\mathrm{Mg} \#$ and $\mathrm{Al}_{2} \mathrm{O}_{3}, \mathrm{CaO}$ contents (Fig. 3), suggesting that they underwent similar depletion and refertilization processes. Therefore, the low water contents in olivine are consistent with the high-degree melt extraction as indicated by high $\mathrm{Mg} \#$ for both olivine and the whole rock.

On the other hand, the Almklovdalen and Tafjord chlorite peridotites experienced pervasive multistage fluid infiltration and retrogression during late Caledonian uplift (Kostenko et al., 2002). The consistent 
foliation and lineation defined by chlorite, tremolite and olivine in the chlorite peridotites suggest that olivine was recrystallized at amphibolite facies conditions in the presence of water, which seems contrary to the measured low water contents in olivine. To resolve this paradox, we must evaluate the effect of hydrogen diffusion on the water concentration in olivine during exhumation from the upper mantle to the crust.

The effect of hydrogen diffusion can be quantified by

$$
l=\sqrt{D^{\mathrm{eff}} t}
$$

where $l$ is the characteristic distance in metres, $D^{\mathrm{eff}}$ is the effective diffusion coefficient of olivine in $\mathrm{m}^{2} \mathrm{~s}^{-1}$, and $t$ is the time in seconds (Crank, 1956). $D^{\text {eff }}$ of olivine includes the hydrogen diffusion in the lattice and along grain boundaries and can be described by the Arrhenius law (Demouchy, 2010):

$$
D^{\mathrm{eff}}=D^{L}+(3 \delta / d) D^{\mathrm{gb}}
$$

where $D^{\mathrm{L}}$ is the hydrogen diffusion coefficient along the fastest direction in olivine lattice, that is, the [100] direction for the 'proto-polaron' mechanism (Mackwell \& Kohlstedt, 1990), $D^{\mathrm{gb}}$ is the hydrogen diffusion coefficient along grain boundaries, $d$ is the grain size, $\delta$ is the grain boundary width and is set to be $0.75 \mathrm{~nm}$ (two monoatomic layers). At $\geq 900{ }^{\circ} \mathrm{C}$, the grain boundary term $(3 \delta / d) D^{\mathrm{gb}}$ for a grain size of $1 \mathrm{~mm}$ is $1-2$ orders of magnitude smaller than $D^{[100]}$, leading to $D^{\text {eff }} \approx D^{[100]}$ (Fig. S9a). Therefore, at upper mantle conditions, hydrogen transport in unsaturated coarsegrained rocks would be controlled by the lattice diffusion, which will yield very limited diffusion distance and ensure the survival of water heterogeneity in the upper mantle (Demouchy, 2010). However, at 600$800{ }^{\circ} \mathrm{C}$, the grain boundary term $(3 \delta / d) D^{\mathrm{gb}}$ for a grain size of $0.1 \mathrm{~mm}$ is much higher than $D^{[100]}$, suggesting significant hydrogen diffusion along grain boundaries in fine-grained peridotites. Therefore, in a cold subducted slab, grain boundaries will behave as an efficient pathway for hydrogen transport before development of fractures. The reduction of grain size by dynamic recrystallization will enhance the hydrogen diffusion along grain boundaries and result in the growth of chlorite and tremolite along grain boundaries of 'dry' olivine in mylonitic peridotites. At $<500{ }^{\circ} \mathrm{C}$ (i.e., in the middle to upper crust), the effective hydrogen diffusion is too slow to alter the water concentration of olivine (Fig. S9b). The fluid infiltration was facilitated by fracture networks and pervasive dilation of grain boundaries during uplift (Kostenko et al., 2002).

At $600-850{ }^{\circ} \mathrm{C}$, which is the temperature range of eclogite and amphibolite facies metamorphism across the WGR (Fig. 1), the characteristic diffusion distance using Equations (1) and (2) and grain size of $1 \mathrm{~mm}$ yields $5-30 \mathrm{~m}$ for $1 \mathrm{Ma}, 16-94 \mathrm{~m}$ for $10 \mathrm{Ma}$, and $51-297 \mathrm{~m}$ for $100 \mathrm{Ma}$ in olivine-rich rocks
(Fig. S9b). Given the fast exhumation rate of the WGR and the size of peridotite bodies, the effect of hydrogen diffusion on water contents of olivine is very limited during exhumation. Hence, the measured values certainly yield an upper bound for the in situ water contents.

\section{Mechanisms for fabric transition in olivine}

The water-induced fabric transition in olivine was first reported by Jung \& Karato (2001). In their olivine fabric diagram for high-temperature conditions, the dominant slip system will change from the [100](010) (A-type) at low stress or $[100]\{0 k l\}$ (D-type) at high stress in 'dry' olivine $\left(<200 \mathrm{H} 10^{-6} \mathrm{Si}\right)$, to $[100](001)$ (E-type) with moderate water content (200-1000 $\left.\mathrm{H} 10^{-6} \mathrm{Si}\right)$ and low stress, and to either $[001](010)$ (B-type) at high stress or [001](100) (C-type) at low stress in 'wet' olivine $\left(>1000 \mathrm{H} 10^{-6} \mathrm{Si}\right.$ ) (Jung \& Karato, 2001; Katayama et al., 2004). Our samples show very low water contents in olivine; as a result, the A- or the D-type fabric would be expected at low or high stress, respectively. However, the independence of olivine water contents and fabric types (Table 3) indicates that in this case, water is not the key parameter for the fabric transition in olivine.

In fact, olivine samples in laboratory deformation experiments contain much higher water contents than orogenic peridotites from UHP terranes (Wang, 2010), and were subjected to much higher temperatures (typically $1200-1300{ }^{\circ} \mathrm{C}$ ) than in a subducted slab (650-900 ${ }^{\circ} \mathrm{C}$; Fig. 1). Early deformation experiments revealed the dominance of $[100](010)$ slip system at high temperature and low strain rate, and a change of slip direction in olivine from [001] to [100] with increasing temperature and decreasing strain rate (Raleigh, 1968; Carter \& Avé Lallemant, 1970; Zhang et al., 2000). Recent experiments and theoretical modelling have demonstrated the pressure-induced slip transition from [100](010) to [001](010) in dry olivine at pressures $>3 \mathrm{GPa}$ (Couvy et al., 2004; Mainprice et al., 2005; Raterron et al., 2007; Jung et al., 2009; Ohuchi et al., 2011). Therefore, the activation of [001] slip in olivine may result from dislocation creep at conditions of low temperature, HP and/or high strain rate.

The subduction-related $P-T$ gradient across the WGR has not been significantly disrupted by the later exhumation-related, amphibolite facies, protomylonitic fabrics (Hacker et al., 2010), which provides an opportunity to preserve the olivine fabrics formed in earlier episodes. It is interesting to note that the C-type olivine fabric was observed in the highly depleted garnet harzburgites from Otrøy. The multistage generation of majoritic garnet in the Nordøyane UHP domain records a complex evolution history: Archean upwelling and accretion to subcratonic lithosphere (M1), isobaric cooling until the Middle Proterozoic (M2), and subduction to a depth of $\sim 200 \mathrm{~km}$ within 
the Baltic continental crust during the Scandian orogeny (M3) in the diamond-eclogite facies (850$950^{\circ} \mathrm{C}$ and 5.5-6.5 GPa) (Van Roermund, 2009). Compared with previous deformation experiments, the C-type olivine fabric in garnet harzburgites from Otrøy should be formed under the M3 stage characterized by ultrahigh-pressure, low temperature and low geothermal gradient $\left(<5^{\circ} \mathrm{C} \mathrm{km}^{-1}\right)$, and dry conditions. Our explanation is consistent with the occurrence of microdiamond and majoritic garnet in the peridotites within the deeply subducted continental crust (Brueckner et al., 2002; Spengler et al., 2006; Vrijmoed et al., 2006; Scambelluri et al., 2008), and the northwestward increase in temperature and pressure across the WGR (Fig. 1). A similar case has been recognized in the Zhimafang garnet peridotites from the Sulu UHP terrane, China (Xu et al., 2006), suggesting that the C-type olivine fabric can be regarded as an indicator of UHP and low geothermal gradient in the upper mantle.

The garnet lherzolites and dunites from the Almklovdalen and Tafjord areas show very complex microstructures with A-, B- and E-type fabrics of olivine. The Almklovdalen peridotite body is a sheath fold in the HP/UHP transition with $>2.4 \mathrm{GPa}$ and $700{ }^{\circ} \mathrm{C}$, and is located in the hinge zone of the Nordfjord-Stadlandet antiform formed under the amphibolite facies conditions (Fig. 1). The ultramafic masses in the Tafjord area occur within recumbent folds, and were also strongly sheared together with the enclosing gneisses under granulite to amphibolite facies conditions. The mantle peridotites could be tectonically emplaced into the crustal slab either during subduction or subsequent exhumation. The lack of prograde metamorphic features in garnet peridotites from Almklovdalen and Tafjord led Brueckner et al. (2010) to propose that these peridotite bodies were transferred from the mantle wedge into the continental crust during exhumation of the WGR in the late stages of the Scandian orogeny. However, Griffin \& Qvale (1985) documented that Fe-rich eclogite lenses within the Raudkleivane peridotite body in Almklovdalen contain prograde-zoned garnet, suggesting that the Raudkleivane peridotite body was captured by the subducting Baltic crust and experienced the Scandian prograde metamorphism from amphibolite to eclogite facies. The lack of garnet growth at UHP conditions may be caused by the incomplete metamorphic transformation during the short-lived UHP event in the southern WGR (Carswell et al., 2003).

At $650-750{ }^{\circ} \mathrm{C}$, [001](010) slip in olivine is dominant at high strain rate, both in the presence and absence of water (Carter \& Avé Lallemant, 1970; Couvy et al., 2004). Therefore, the B-type olivine fabric in the Almklovdalen and Tafjord peridotites was formed under low temperature, high differential stress and high strain rate in shear zones, which is consistent with the strong porphyroclastic to mylonitic textures in these samples. Given the stability field of chlorite peridotites, the B-type fabric of these peridotites was probably formed at amphibolite facies conditions ( 0.5 $1.5 \mathrm{GPa}$ and $650-750{ }^{\circ} \mathrm{C}$ ) during exhumation of the WGR. Systematic EBSD measurements on oriented samples will help to confirm this interpretation. The formation of orogenic fabrics within a crustal package can provide important information on mantle deformation and seismic anisotropy in some cases. For example, the C-type olivine fabric may develop at a depth $>150 \mathrm{~km}$ beneath cratons. The B-type olivine fabric may be dominant in mantle shear zones, such as the interface between the subducted slab and the mantle wedge, the lithosphere-asthenosphere boundary beneath a continental rift, and strain localization associated with water-induced partial melting.

The A-type fabric in the weakly deformed dunites, however, probably represents an original fabric that formed under high temperature and low strain rate in the mantle wedge. This A-type olivine fabric is widely observed in mantle xenoliths and ophiolite complexes (Ben Ismaïl \& Mainprice, 1998). Similarly, garnet wehrlites from Gurskebotn in the eclogite facies HP domain also preserve the relict A-type fabric of olivine. The activation of [100](001) slip system in garnet lherzolite N97-14 may be enhanced by the high stress and localized high fluid activity under HP/UHP transition conditions, as suggested by its porphyroclastic texture and relatively high water contents in small recrystallized olivine grains (Table 3 ).

It is noteworthy that recrystallized olivine grains may develop a fabric different from the coarse porphyroclasts. For example, garnet wehrlite protomylonite N97-30 from Gurskebotn records a gradual transition from the A-type fabric in porphyroclasts to the B-type fabric in recrystallized grains during shearing. The coexistence of both $[001](010)$ and [001](100) slip systems in dunite mylonite K-i-I from Tafjord probably reflects water-enhanced activity of the [001](100) slip system at high strain rate and low temperature, as shown by stronger fabric strength and relatively high water contents in recrystallized small grains, distribution of chlorite and tremolite in grain boundaries, and the consistent foliation and lineation of olivine and the hydrous minerals. The lack of the dominant C-type fabric in the Almklovdalen, Tafjord and Gurskebotn peridotites suggests that these samples were not subjected to high enough pressures as those in the Nordøyene UHP terrane during the Scandian orogeny.

\section{CONCLUSIONS}

An integrated study of geochemistry, microstructures and water contents of garnet peridotites and dunites from four areas of the WGR provides new insights into the fabric transition of olivine in continental subduction zones. The highly depleted dunites represent Archean mantle fragments in Proterozoic crust, while the garnet peridotites resulted from Proterozoic refertil- 
ization of the dunites by melt percolation. They were introduced into the subducted Proterozoic Baltic shield and experienced HP to UHP metamorphism and deformation during the Scandian orogeny. The very low water contents of olivine are consistent with the high-degree melt extraction of the peridotites. The hydrogen diffusion on the water contents of olivine during exhumation is very limited due to the relatively low temperature and coarse grain size. The garnet peridotites from Otrøy are comparable with the Zhimafang garnet peridotites from the Sulu terrane (China) (Xu et al., 2006) in their high-degree partial melting, the C-type olivine fabric, low water content, and the UHP metamorphism conditions of $>6 \mathrm{GPa}$ and $850-950{ }^{\circ} \mathrm{C}$. Therefore, the C-type fabric of olivine can be an indicator of an ultradeep origin for mantle rocks, especially in a dry and cold subducted continental slab. The B-type olivine fabric is observed in strongly sheared HP garnet peridotites and dunites from the Almklovdalen and Tafjord areas, suggesting the dominant activation of [001](010) slip system at high stress and high strain rate. The A-type olivine fabric in peridotites from the eclogite facies HP domain preserves the relict fabric in the mantle wedge before they were caught into the subduction zone.

The calculated seismic anisotropy of the peridotites from the WGR shows complex patterns. The pressureinduced fabric transition of olivine from the A- to C-type fabric will result in a characteristic change in P-wave anisotropy and shear wave splitting with increasing depth. The dominance of the olivine C-type fabric will make the maximum $V p$ and the polarization plane of the fast $\mathrm{S}$-wave normal to the foliation. However, the stress-induced transition from the A- to B-type fabric is probably localized in mantle shear zones and will not be distinguishable in seismic anisotropy observations.

\section{ACKNOWLEDGEMENTS}

Three samples from Tafjord were collected by HKB, and all the other samples were provided by WLG and SYO'R. We thank F. Y. Chen, H. J. Xu and J. Li for help with the EBSD analysis, and Q. B. Men in the EMP analysis. This manuscript benefited from constructive discussion with D. Mainprice, L. Dobrzhinetskaya and W. Müller, and thoughtful comments and suggestions of two anonymous reviewers. Q. Wang is grateful to Prof. G. Hoinkes for his patience and support to this paper. This research was funded by the NCET programme (NCET-08-0275), NSFC project (40921002), SinoProbe programme (DD09-114), and grant (2008-II-05) from the State Key Laboratory for Mineral Deposits Research (Nanjing University). The analytical work at GEMOC used instrumentation funded by DEST Systemic Infrastructure Grants, ARC LIEF, NCRIS, industry partners and Macquarie University. This is contribution 200 from ARC Centre of Excellence for Core to Crust Fluid Systems (http://www.ccfs.mq.edu.au) and contribution 841 from the GEMOC Key Centre (http://www. gemoc.mq.edu.au).

\section{REFERENCES}

Abramson, E.H., Brown, J.M., Slutsky, L.J. \& Zang, J., 1997. The elastic constants of San Carlos olivine to $17 \mathrm{GPa}$. Journal of Geophysical Research, 102, 12253-12263.

Austreim, H., Corfu, F., Bryhni, I. \& Andersen, T.B., 2003. The Proterozoic Hustad complex: a low strain enclave with a key to the history of the Western Gneiss Region of Norway. Precambrian Research, 120, 149-175.

Bascou, J., Tommasi, A. \& Mainprice, D., 2002. Plastic deformation and development of clinopyroxene lattice preferred orientations in eclogites. Journal of Structural Geology, 24, 1357-1368.

Bell, D.R., Rossman, G.R., Maldener, J., Endisch, D. \& Rauch, F., 2003. Hydroxide in olivine: a quantitative determination of the absolute amount and calibration of the IR spectrum. Journal of Geophysical Research, 108, B2, 2105, doi:10.1029/ 2001JB000679.

Ben Ismaïl, W. \& Mainprice, D., 1998. An olivine fabric database: an overview of upper mantle fabrics and seismic anisotropy. Tectonophysics, 269, 145-157.

Beyer, E.E., Brueckner, H.K., Griffin, W.L., O’Reilly, S.Y. \& Graham, S., 2004. Archean mantle fragments in Proterozoic crust, Western Gneiss Region, Norway. Geology, 32, 609612.

Beyer, E.E., Griffin, W.L. \& O'Reilly, S.Y., 2006. Transformation of Archaean lithospheric mantle by refertilization: evidence from exposed peridotites in the Western Gneiss Region, Norway. Journal of Petrology, 47, 1611-1636.

Beyer, E.E., Brueckner, H.K., Griffin, W.L. \& O'Reilly, S.Y., 2012. Laurentian provenance of Archean mantle fragments in Proterozoic Baltic crust of the Norwegian Caledonides. Journal of Petrology, 53, 1357-1383.

Blackman, D.K., Wenk, H.-R. \& Kendall, J.M., 2000. Seismic anisotropy of the upper mantle, 1, Factors that affect mineral texture and effective elastic properties. Geochemistry Geophysics Geosystems, 3, 8601, doi:10.1029/2001GC000248.

Brueckner, H.K., 1969. Timing of ultramafic intrusion in the core zone of the Caledonids of southern Norway. American Journal of Science, 267, 1195-1212.

Brueckner, H.K., 1977. A structural, stratigraphic and petrologic study of anorthosites, eclogites and ultramafic rocks and their country rocks, Tafjord Area, Western South Norway. Norges Geologiske Undersøkelse, 332, 53p.

Brueckner, H.K. \& Medaris, L.G., 2000. A general model for the intrusion and evolution of 'mantle' garnet peridotites in highpressure and ultra-high-pressure metamorphic terranes. Journal of Metamorphic Geology, 18, 123-133.

Brueckner, H.K., Carswell, D.A. \& Griffin, W.L., 2002. Paleozoic diamonds within a Precambrian peridotite lens in UHP gneisses of the Norwegian Caledonides. Earth and Planetary Science Letters, 203, 805-816.

Brueckner, H.K., Carswell, D.A., Griffin, W.L., Medaris, L.G., Van Roermund, H.L.M. \& Cuthbert, S.J., 2010. The mantle and crustal evolution of two garnet peridotite suites from the Western Gneiss Region, Norwegian Caledonides: an isotopic investigation. Lithos, 117, 1-19.

Carswell, D.A., 1968. Possible primary upper mantle peridotite in Norwegian basal gneiss. Lithos, 1, 322-355.

Carswell, D.A. \& Cuthbert, S.J., 2003. Ultrahigh pressure metamorphism in the western Gneiss Region of Norway. In: Ultrahigh Pressure Metamorphism (eds Carswell, D.A. \& Compagnoni, R.), EMU Notes in Mineralogy, 5, 51-73.

Carswell, D.A., Brueckner, H.K., Cuthbert, S.J., Mehta, K. \& O'Brien, P.J., 2003. The timing of stabilisation and the exhumation rate for ultra-high pressure rocks in the Western 
Gneiss Region of Norway. Journal of Metamorphic Geology, 21, 601-612.

Carter, N.L. \& Avé Lallemant, H.G., 1970. High temperature flow of dunite and peridotite. Geological Society of American Bulletin, 81, 2181-2202.

Chai, M., Brown, J.M. \& Slutsky, L.J., 1997. The elastic constants of an aluminous orthopyroxene to $12.5 \mathrm{GPa}$. Journal of Geophysical Research, 102, 14779-14785.

Collins, M.D. \& Brown, J.M., 1998. Elasticity of an upper mantle clinopyroxene. Physics and Chemistry of Minerals, $\mathbf{2 6}$ $7-13$.

Cordellier, F.M., Boudier, F. \& Boullier, A.M., 1981. Structural study of the Almklovdalen peridotite massif (southern Norway). Tectonophysics, 77, 257-281

Couvy, H., Frost, D.J., Heidelbach, F. et al., 2004. Shear deformation experiments of forsterite at $11 \mathrm{GPa}-1400{ }^{\circ} \mathrm{C}$ in the multianvil apparatus. European Journal of Mineralogy, 16, 877-889.

Crank, J., 1956. The Mathematics of Diffusion. Oxford University Press, Oxford.

Demouchy, S., 2010. Diffusion of hydrogen in olivine grain boundaries and implications for the survival of water-rich zones in the Earth's mantle. Earth and Planetary Science Letters, 295, 305-313.

Dobrzhinetskaya, L., Eide, E.A., Larsen, R.B. et al., 1995. Microdiamond in high-grade metamorphic rocks of the Western Gneiss region, Norway. Geology, 23, 597-600.

Druiventak, A., Matysiak, A.K., Renner, J. \& Trepmann, C.A. 2012. Kick-and-cook experiments on peridotite: simulating coseismic deformation and postseismic creep. Terra Nova, 24, $62-69$.

Durinck, J., Legris, A. \& Cordier, P., 2005. Pressure sensitivity of olivine slip systems: first-principle calculations of generalized stacking faults. Physics and Chemistry of Minerals, 32 , 646-654.

Frese, K., Trommsdorf, V. \& Kunze, K., 2003. Olivine [100] normal to foliation: lattice preferred orientation in prograde garnet peridotite formed at high $\mathrm{H}_{2} \mathrm{O}$ activity, Cima di Gagnone (Central Alps). Contributions to Mineralogy and Petrology, 145, 73-86.

Godard, G. \& Van Roermund, H.L.M., 1995. Deformation-induced clinopyroxene fabrics from eclogite. Journal of Structural Geology, 17, 1425-1443.

Griffin, W.L. \& Qvale, H., 1985. Superferrian eclogites and the crustal origin of garnet peridotites, Almklovdalen, Norway. In: The Caledonide Orogen Scandinavia and Related Areas (eds Gee, D.G. \& Sturt, B.A..), pp. 803-812. Wiley, Chichester.

Griffin, W.L., O'Reilly, S.Y., Abe, N. et al., 2003. The origin and evolution of Archean lithospheric mantle. Precambrian Research, 127, 19-41.

Hacker, B.R., 2007. Ascent of the ultrahigh-pressure Western Gneiss Region, Norway. In: Convergent Margin Terranes and Associated Regions: A Tribute to W.G. Ernst (eds Cloos, M., Carlson, W.D., Gilbert, M.C. et al.), pp. 171-184. Geological Society of America Special Paper 419, Geological Society of America, Boulder, CO.

Hacker, B.R., Andersen, T.B., Johnston, S. et al., 2010. Hightemperature deformation during continental-margin subduction \& exhumation: the ultrahigh-pressure Western Gneiss Region of Norway. Tectonophysics, 480, 149-171.

Jamtveit, B., 1984. High-P metamorphism and deformation of the Gurskebotn garnet peridotite, Sunnmore, Western Norway. Norsk Geologisk Tidsskrift, 64, 97-110.

Ji, S.C., Wang, Q. \& Xu, Z.Q., 2007. Reply to the comments of S. Karato on "Petrofabrics and seismic properties of garnet peridotites from the UHP Sulu terrane (China)" by Xu et al. [Tectonophysics 421 (2006) 111-127]. Tectonophysics, 429, 291-296.

Jung, H. \& Karato, S., 2001. Water-induced fabric transitions in olivine. Science, 293, 1460-1463.

Jung, J., Katayama, I., Jiang, Z., Hiraga, T. \& Karato, S., 2006. Effect of water and stress on the lattice-preferred orientation of olivine. Tectonophysics, 421, 1-22.
Jung, H., Mo, W. \& Green, H.W., 2009. Upper mantle seismic anisotropy resulting from pressure-induced slip transition in olivine. Nature Geoscience, 2, 73-77.

Karato, S., Jung, H., Katayama, I. \& Skmer, P., 2008. Geodynamic significance of seismic anisotropy of the upper mantle: new insights from laboratory studies. Annual Review of Earth and Planetary Sciences, 36, 59-95.

Katayama, I. \& Karato, S., 2006. Effect of temperature on the Bto C-type olivine fabric transition and implication for flow pattern in subduction zones. Physics of the Earth and Planetary Interiors, 157, 33-45.

Katayama, I., Jung, H. \& Karato, S., 2004. New type of olivine fabric from deformation experiments at modest water content and low stress. Geology, 32, 1045-1048.

Katayama, I., Karato, S. \& Brandon, M., 2005. Evidence of high water content in the deep upper mantle inferred from deformation microstructures. Geology, 33, 613-616.

Khisina, N.R., Wirth, R., Andrut, M. \& Ukhanov, A.V., 2001. Extrinsic and intrinsic modes of hydrogen occurrence in natural olivine: FTIR and TEM investigation. Physics and Chemistry of Minerals, 28, 291-301.

Kostenko, O., Jamtveit, B., Austrheim, H., Pollok, K. \& Putnis, C., 2002. The mechanism of fluid infiltration in peridotites at Almklovdalen, western Norway. Geofluids, 2, 203-215.

Kovacs, I., Hermann, J., O'Neill, H.S.C., Gerald, J.F., Sambridge, M. \& Horvath, G., 2008. Quantitative absorbance spectroscopy with unpolarized light: Part II. Experimental evaluation and development of a protocol for quantitative analysis of mineral IR spectra. American Mineralogist, 93, 765-778.

Kylander-Clark, A.R.C., Hacker, B.R. \& Mattinson, J.M., 2008. Slow exhumation of UHP terranes: titanite and rutile ages of the Western Gneiss Region, Norway. Earth and Planetary Science Letters, 272, 531-540.

Lapen, T.J., Medaris, L.G., Johnson, C.M., Beard, B.L. \& Johnson, C.M., 2009. The Sandvik peridotite, Gurskøy, Norway: three billion years of mantle evolution in the Baltica lithosphere. Lithos, 109, 145-154.

Long, M.D. \& Becker, T.W., 2010. Mantle dynamics and seismic anisotropy. Earth and Planetary Science Letters, 297, 341-354.

Mackwell, S.J. \& Kohlstedt, D.L.. 1990. Diffusion of hydrogen in olivine: implications for water in the mantle. Journal of Geophysical Research, 95 (B4), 5079-5088.

Mainprice, D., Bascou, J., Cordier, P. \& Tommasi, A., 2004. Crystal preferred orientations of garnet: comparison between numerical simulations and electron back-scattered diffraction (EBSD) measurements in naturally deformed eclogites. Journal of Structural Geology, 26, 2089-2102.

Mainprice, D., Tommasi, A., Couvy, H., Cordier, P. \& Frost, D.J., 2005. Pressure sensitivity of olivine slip systems and seismic anisotropy of Earth's upper mantle. Nature, 433, 731-733.

Matysiak, A.K. \& Trepmann, C.A.. 2012. Crystal-plastic deformation and recrystallization of peridotite controlled by the seismic cycle. Tectonophysics, 530-531, 111-127.

McDonough, W.F. \& Sun, S.-S., 1995. The composition of the Earth. Chemical Geology, 120, 223-253.

Medaris, L.G., 1980. Petrogenesis of the Lien peridotite and associated eclogites, Almklovdalen, western Norway. Lithos, 13, 339-353.

Mercier, J.C.C., 1985. Olivine and pyroxenes. In: Preferred Orientation in Deformed Metals and Rocks: An Introduction to Modern Texture Analysis (ed. Wenk, H.R..), pp. 407-430. Academic Press, Orlando.

Miller, G.H., Rossman, G.R. \& Harlow, G.E., 1987. The natural occurrence of hydroxide in olivine. Physics and Chemistry of Minerals, 14, 461-472.

Ohuchi, T., Kawazoe, T., Nishihara, Y., Nishiyama, N. \& Irifune, T., 2011. High pressure and temperature fabric transitions in olivine and variations in upper mantle seismic anisotropy. Earth and Planetary Science Letters, 304, 55-63. 
Park, J. \& Levin, V., 2002. Seismic anisotropy: tracing plate dynamics in the mantle. Science, 296, 485-489.

Paterson, M.S., 1982. The determination of hydroxyl by infrared absorption in quartz silicate glasses and similar materials. Bulletin of Mineralogy, 105, 20-29.

Raleigh, C.B., 1968. Mechanisms of plastic deformation of olivine. Journal of Geophysical Research, 73, 5391-5406.

Raterron, P., Chen, J.H., Li, L., Weidner, D. \& Cordier, P., 2007. Pressure-induced slip-system transition in forsterite: single-crystal rheological properties at mantle pressure and temperature. American Mineralogist, 92, 1436-1445.

Root, D.B., Hacker, B.R., Gans, P.B., Ducea, M.N., Eide, E.A. \& Mosenfelder, J.L., 2005. High-pressure allochthons overlie the ultrahigh-pressure Western Gneiss Region, Norway. Journal of Metamorphic Geology, 23, 45-61.

Savage, M.K., 1999. Seismic anisotropy and mantle deformation: what have we learned from shear wave splitting? Review of Geophysics, 37, 65-106.

Scambelluri, M., Pettke, T. \& Van Roermund, H.L.M., 2008. Majoritic garnets monitor deep subduction fluid flow and mantle dynamics. Geology, 36, 59-62.

Skår, Ø. \& Pedersen, R.B., 2003. Relations between granitoid magmatism and migmatization: $\mathrm{U}-\mathrm{Pb}$ geochronological evidence from the Western Gneiss Complex, Norway. Journal of the Geological Society of London, 160, 935-946.

Skemer, P., Katayama, I. \& Karato, S., 2006. Deformation fabrics of the Cima di Gagnone peridotite massif, Central Alps, Switzerland: evidence of deformation at low temperatures in the presence of water. Contributions to Mineralogy and Petrology, 152, 43-51.

Spengler, D., Van Roermund, H.L.M., Drury, M.R., Ottolini, L., Mason, P.R.D. \& Davies, G.R., 2006. Deep origin and hot melting of an Archean orogenic peridotite massif in Norway. Nature, 440, 913-917.

Terry, M.P. \& Robinson, P., 2003. Evolution of amphibolitefacies structural features and boundary conditions for deformation during exhumation of high- and ultrahigh-pressure rocks, Nordøyane, Western Gneiss Region, Norway. Tectonics, 22, 1036

Terry, M.P. \& Robinson, P., 2004. Geometry of eclogite-facies structural features: implications for production and exhumation of UHP and HP rocks, Western Gneiss Region, Norway. Tectonics, 23, TC2001.

Tommasi, A., Mainprice, D., Canova, G. \& Chastel, Y., 2000. Viscoplastic self-consistent and equilibrium-based modeling of olivine lattice preferred orientations: implications for the upper mantle seismic anisotropy. Journal of Geophysical Research, 105, 7893-7908.

Torsvik, T.H., 1998. Palaeozoic palaeogeography: a North Atlantic viewpoint. $G F F, \mathbf{1 2 0}, 109-118$.

Van Roermund, H.L.M., 2009. Mantle-wedge garnet peridotites from the northernmost ultra-high pressure domain of the Western Gneiss Region, SW Norway. European Journal of Mineralogy, 21, 1085-1096.

Van Roermund, H.L.M., Carswell, D.A., Drury, M.R. \& Heijboer, T.C., 2002. Microdiamonds in a megacrystic garnet websterite pod from Bardane on the island of Fjørtoft, western Norway: evidence for diamond formation in mantle rocks during deep continental subduction. Geology, 30, 959-962.

Vrijmoed, J.C., Van Roermund, H.L.M. \& Davies, G., 2006. Evidence for diamond-grade UHP metamorphism and fluid interaction in the Svartberget Fe-Ti garnet peridotite/websterite body, Western Gneiss Region, Norway. Mineralogy and Petrology, 88, 381-405.

Wang, Q., 2010. A review of water contents and ductile deformation mechanisms of olivine: implications for the lithosphereasthenosphere boundary of continents. Lithos, 120, 30-41.

Wang, Q., Burlini, L., Mainprice, D. \& Xu, Z.Q., 2009. Geochemistry, petrofabrics and seismic properties of eclogites from the Chinese Continental Scientific Drilling boreholes in the Sulu UHP terrane, eastern China. Tectonophysics, 475, 251-266.

Whitney, D.L. \& Evans, B.W., 2010. Abbreviations for names of rock-forming minerals. American Mineralogist, 95, 185-187.

Xu, Z.Q., Wang, Q., Ji, S.C. et al., 2006. Petrofabrics and seismic properties of garnet peridotite from the UHP Sulu terrane (China): implications for olivine deformation mechanism in a cold and dry subducting continental slab. Tectonophysics, 421, 111-127.

Zhang, S., Kararo, S., Fitz Gerald, J., Faul, U.H. \& Zhou, Y., 2000. Simple shear deformation of olivine aggregates. Tectonophysics, 316, 133-152.

\section{SUPPORTING INFORMATION}

Additional Supporting Information may be found in the online version of this article:

Appendix S1. Analytical methods.

Figure S1. Equal-area lower hemisphere projection of olivine crystal axis distribution for recrystallized small grains using a step size of $10 \mu \mathrm{m}$ in the EBSD analysis.

Figure S2. Equal-area lower hemisphere projection of olivine crystal axis distribution for sample N97-30.

Figure S3. EBSD analysis results of a strongly sheared, porphyroclastic dunite K-i-I.

Figure S4. Equal-area lower hemisphere projection of enstatite crystal axis distribution for the Almklovalen peridotites.

Figure S5. Equal-area lower hemisphere projection of enstatite crystal axis distribution for peridotite samples from Ugelvik, Gurskebotn and Kallskaret.

Figure S6. Equal-area lower hemisphere projection of diopside crystal axis distribution for the WGR peridotites.

Figure S7. Equal-area lower hemisphere projection for seismic properties of olivine, enstatite and diopside.

Figure S8. Calculated seismic properties of 100\% olivine and $100 \%$ enstatite aggregates using the EBSDderived CPO data for samples N97-5, N97-9 and N97-14.

Figure S9. (a) Arrhenius diagram of various hydrogen diffusivities and (b) the effective hydrogen diffusion distance of olivine for 1,10 and $100 \mathrm{Ma}$ using grain size of $1 \mathrm{~mm}$.

Table S1. Whole-rock major-element abundances $(\mathrm{wt} \%$ ) for peridotites from the Western Gneiss Region.

Table S2. Major-element abundances ( $\mathrm{wt} \%$ ) of olivine from peridotites in the Western Gneiss Region.

Table S3. Major-element abundances ( wt $\%$ ) of orthopyroxene from peridotites in the Western Gneiss Region.

Table S4. Major-element abundances (wt $\%$ ) of clinopyroxene from peridotites in the Western Gneiss Region.

Received 16 March 2012; revision accepted 25 September 2012. 